\title{
Strong contribution of diatom resting spores to deep-sea carbon transfer in naturally iron-fertilized waters downstream of South Georgia
}

\author{
M. Rembauville ${ }^{\mathrm{a}, *}$, C. Manno ${ }^{\mathrm{b}}$, G.A. Tarling ${ }^{\mathrm{b}}$, S. Blain ${ }^{\mathrm{a}}$, I. Salter ${ }^{\mathrm{a}, \mathrm{c}}$ \\ a Sorbonne Universités, UPMC Univ Paris 06, CNRS, Laboratoire d'Océanographie Microbienne (LOMIC), Observatoire Océanologique, F-66650 Banyuls/mer, \\ France \\ ${ }^{\mathrm{b}}$ British Antarctic Survey, Natural Environmental Research Council, High Cross, Madingley Road, Cambridge CB3 OET, UK \\ ${ }^{\mathrm{c}}$ Alfred-Wegener-Institute for Polar and Marine research, Bremerhaven, Germany
}

\section{A R T I C L E I N F O}

\section{Article history:}

Received 4 January 2016

Received in revised form

2 May 2016

Accepted 5 May 2016

Available online 7 May 2016

Keywords:

Carbon export

Southern Ocean

Diatom resting spores

Natural iron fertilization

\begin{abstract}
A B S T R A C T
Biogeochemical and diatom export fluxes are presented from two bathypelagic sediment trap deployments in the Antarctic Zone of the Southern Ocean. One of the sediment traps was deployed in very productive, naturally iron-fertilized waters downstream of South Georgia (P3, $2000 \mathrm{~m}$ ) and compared to a deployment in moderately productive waters upstream of the island system (P2, $1500 \mathrm{~m})$. At both sites significant diatom export events occurred in spring (November) and contained mostly empty cells that were associated with low particulate organic carbon (POC) fluxes. A summer export pulse occurred one month later at P2 (end February/March) compared to P3 (end January). Diatom fluxes at P3 were one order of magnitude higher than at $\mathrm{P} 2$, a difference mainly attributed to the short and intense export of resting spores from Chaetoceros Hyalochaete and Thalassiosira antarctica species. Aside from these resting spores, diatom export assemblages at both sites were dominated by empty Fragilariopsis kerguelensis frustules. The fraction of diatoms exported as empty frustules was considerably lower at P3 (52\%) than P2 (91\%). This difference was related to the flux of intact diatom resting spores at P3 and may partially explain the lower Si:C export stoichiometry observed at P3 (1.1) compared to P2 (1.5). Through the enumeration of full diatom frustules and subsequent biomass calculations we estimate that diatom resting spores account for $42 \%$ of annual POC flux in the productive waters downstream of South Georgia. At both sites the contribution of diatom vegetative stages to POC fluxes was considerably lower $(<5 \%)$. From these analyses we conclude that resting spore export contributes towards the slightly higher bathypelagic (POC) flux at P3 $\left(40.6 \mathrm{mmol} \mathrm{m}^{-2} \mathrm{y}^{-1}\right)$ compared to P2 $\left(26.4 \mathrm{mmol} \mathrm{m}^{-2} \mathrm{y}^{-1}\right)$. We compared our sediment trap records with previously published diatom assemblage data from the mixed layer and surface sediments $(3760 \mathrm{~m})$ around South Georgia. The relative proportion of diatom resting spores within diatom assemblages increases as a function of depth and is explained by selective preservation of their robust frustules. Our study highlights the significance of diatom resting spore export as a carbon vector out of the mixed layer. Furthermore, the contribution or resting spores to POC flux in the bathypelagic ocean and sediments suggests they play a particularly important role in sequestering biologically fixed $\mathrm{CO}_{2}$ over climatically relevant timescales.
\end{abstract}

๑) 2016 Elsevier Ltd. All rights reserved.

\section{Introduction}

The Southern Ocean (SO) is generally considered as the largest high nutrient, low chlorophyll (HNLC) area of the global ocean, where primary production is limited by iron availability (Martin, 1990; de Baar et al., 1990, 1995). Downstream of island plateaus, such as those at Kerguelen (Blain et al., 2001, 2007), Crozet

\footnotetext{
* Corresponding author.

E-mail address: rembauville@obs-banyuls.fr (M. Rembauville).
}

(Pollard et al., 2009) and South Georgia (Whitehouse et al., 1996; Korb and Whitehouse, 2004), shelf sediments and glacial melt waters are a natural source of iron. These naturally-fertilized waters contrast strongly with surrounding HNLC conditions and display large scale phytoplankton blooms that can persist for several months (Westberry et al., 2013). In addition to the island mass effect (Blain et al., 2001), trace metal inputs into surface waters can sustain notable primary production (Moore and Abbott, 2000; Whitehouse et al., 2012) from upwelling associated with major fronts of the Antarctic Circumpolar Current (Loscher et al., 1997), atmospheric dust deposition (Meskhidze et al., 2007), sea 
ice melt (van der Merwe et al., 2011), glacial runoff (Hawkings et al., 2014; van der Merwe et al., 2015) and melting icebergs (Duprat et al., 2016). Primary production downstream of subantarctic island systems is typically dominated by diatoms (Smetacek et al., 2004; Quéguiner, 2013), a microphytoplankton group generally considered to promote carbon export out of the mixed layer directly by sinking (Smetacek, 1985; Boyd and Newton, 1995, 1999) or indirectly by sustaining faecal pellet-productive food webs (Smetacek et al., 2004; Manno et al., 2014).

Maiti et al. (2013) demonstrated an inverse relationship between primary production and export efficiency in the Southern Ocean, contrasting with the positive relationship between primary production and export prevailing in most of the global ocean (Laws et al., 2011). These so called high biomass, low export regimes (HBLE, Lam and Bishop, 2007; Lam et al., 2011) appear to be characterized by enhanced heterotrophic microbial activity (Obernosterer et al., 2008; Christaki et al., 2014) and intense reprocessing and fragmentation of particulate matter by zooplankton. On the Kerguelen Plateau for example, net community production (NCP) was estimated to be $6.6 \mathrm{~mol} \mathrm{~m}^{-2} \mathrm{yr}^{-1}$ (Jouandet et al., 2008), although only a small fraction of this NCP was exported out of the mixed layer (Rembauville et al., 2015b). Annual records of particulate organic carbon (POC) export fluxes derived from moored sediment traps have been published for productive, naturally-fertilized waters downstream of Crozet (Salter et al., 2012), Kerguelen (Rembauville et al., 2015a,b) and South Georgia (Manno et al., 2015). Irrespective of depth (300-2000 m), annual POC export from these island systems exhibits low variability and is typically $<100 \mathrm{mmol} \mathrm{C} \mathrm{m}^{-2} \mathrm{yr}^{-1}$. This finding contrasts with the high levels of productivity associated with these naturally fertilized systems. Identifying the dominant export vectors from such systems is therefore necessary to advance our understanding of the mechanistic relationships between production and export in the Southern Ocean.

A significant positive relationship between POC fluxes and Eucampia antarctica var. antarctica winter stages highlighted its important role as a carbon export vector from the Crozet bloom (Salter et al., 2012). Similarly, quantification of diatom and carbon fluxes from the Kerguelen bloom indicated that $60 \%$ of annual carbon export was due to short term ( $<2$ week) export events of Chaetoceros Hyalochaete and Thalassiosira antarctica resting spores (Rembauville et al., 2015a). Moreover, Salter et al. (2012) and Rembauville et al. (2015a) observed that species-specific diatom ecology (spore formation, protection from grazing through the acquisition of a thick frustule) impacts not only the magnitude of carbon fluxes, but also the Si:C export stoichiometry over annual scales, corroborating previous suggestions (Smetacek, 1985; Smetacek et al., 2004; Salter et al., 2012; Assmy et al., 2013). Downstream of South Georgia, faecal pellets were reported to dominate $(\sim 60 \%)$ the second POC export peak often observed in MarchApril (Manno et al., 2015). However, the contribution of diatoms to bathypelagic POC flux at South Georgia has yet to be addressed.

The waters downstream South Georgia exhibit a large and recurrent phytoplankton bloom (Ward et al., 2002; Borrione and Schlitzer, 2013) characterized by interannual variability in the seasonal pattern (unimodal versus bimodal chlorophyll $a$ peaks, Park et al., 2010; Borrione and Schlitzer, 2013). The bloom is dominated by microplankton diatoms (Korb and Whitehouse, 2004) with a major contribution of Fragilariospsis kerguelensis, Chaetoceros Hyalochaete, Pseudo-nitzschia spp., Eucampia antarctica var. antarctica and Corethron (Korb et al., 2008, 2010). The productive waters downstream of South Georgia support a very large biomass of mesozooplankton (Ward et al., 2012), macrozooplankton (Atkinson et al., 2008, 2009), mesopelagic fish (Collins et al., 2012) and top predators (Boyd et al., 1994), with significant implications for the amount of POC export out of the mixed layer (Huntley et al., 1991). Upstream of South Georgia, the lack of iron limits phytoplankton growth and phytoplankton biomass is one order of magnitude lower than that is observed downstream of the island (Korb et al., 2008). Although the contribution of naked dinoflagellates to microplankton biomass is higher than in naturally-fertilized waters, the diatom species Fragilariospsis kerguelensis, Pseudo-nitzschia spp., small Thalassionema nitzschioides and Chaetoceros Hyalochaete species still dominate the microplankton assemblage (Korb et al., 2010). Korb et al. (2012) hypothesized that differences in diatom community structure upstream and downstream of South Georgia would impact the magnitude of POC export. However, these hypotheses have yet to be addressed by a detailed analysis of diatom export assemblages and elemental fluxes around South Georgia.

In the present study we report diatom and biogeochemical fluxes from two annual sediment trap deployments in varying productivity regimes upstream and downstream of South Georgia. The objectives are (i) to describe spatial and temporal patterns of diatom export assemblages, (ii) to differentiate full and empty frustules to estimate the contribution of specific diatom groups to carbon fluxes and Si:C export stoichiometry and (iii) to compare mixed layer, sediment trap and surface sediment data to describe changes in diatom assemblages as a function of depth.

\section{Materials and methods}

\subsection{Trap deployments and chemical analyses}

Bottom-tethered moorings were deployed at two sites (P2 and P3) for periods of approximately 12 months between January and November 2012. P2 was located upstream of South Georgia (55 $\left.11.99 \mathrm{~S}, \quad 41^{\circ} 07.42 \mathrm{~W}\right)$, and P3 downstream (52 $43.40 \mathrm{~S}$, $40^{\circ} 08.83 \mathrm{~W}$ ) (Fig. 1). Each sediment trap (McLane Parflux conical sediment traps, $0.5 \mathrm{~m}^{2}$ surface collecting area, McLane Labs, Falmouth, MA, USA) was equipped with 12 sample cups and fitted with a plastic baffle mounted in the opening to prevent the entrance of large organisms. Prior to deployment, the sample cups were filled with a preservative seawater solution of $\mathrm{NaCl}$-buffered $\mathrm{HgCl}_{2}$. Traps were deployed at a depth of $1500 \mathrm{~m}$ (P2, water depth $3200 \mathrm{~m}$ ) and $2000 \mathrm{~m}$ (P3, water depth $3800 \mathrm{~m}$ ), and the sample carrousel was programmed to rotate at intervals of 15 days in austral summer and 30 days in austral winter (Table 1). Sample cups for April, July, October (P2) and August (P3) were missing on recovery (unscrewed from the carrousel). Prior to splitting, "swimmers" (i.e. zooplankton organisms that can enter the receiving cups while alive) were carefully removed: samples were first wet-sieved through a $1 \mathrm{~mm}$ nylon mesh and the remaining swimmers were hand-picked under a dissecting microscope. Large aggregates, fragments of moults and empty tests retained by the mesh were returned to the sample. Samples were split in replicate fractions using a McLane rotary sample splitter (McLane Labs, Falmouth, MA, USA). Replicate fractions were vacuum-filtered through preweighed and precalcinated $\left(450^{\circ} \mathrm{C}, 4 \mathrm{~h}\right)$ Whatman $\mathrm{GF} /$ $\mathrm{F}$ filters for POC analyses. Salt content was removed from the filters by a short distilled water rinse and they were dried at $60{ }^{\circ} \mathrm{C}$. For POC determination, filters were treated with $2 \mathrm{~N} \mathrm{H}_{3} \mathrm{PO}_{4}$ and $1 \mathrm{~N}$ $\mathrm{HCl}$ to dissolve the carbonate fraction. $\mathrm{POC}$ was measured by combustion in an elemental analyser (CHN). For biogenic silica (BSi) analyses, replicate fractions were vacuum-filtered through $0.4 \mu \mathrm{m}$ Nuclepore filters. Prior to BSi extraction, the material was pretreated with $10 \% \mathrm{H}_{2} \mathrm{O}_{2}$ and $1 \mathrm{~N} \mathrm{HCl}$ to remove organic particle coatings (Mortlock and Froelich, 1989). BSi was determined by a time-series extraction experiment in a $0.5 \mathrm{M} \mathrm{NaOH}$ solution at $85^{\circ} \mathrm{C}$ for $5 \mathrm{~h}$ (DeMaster, 1981). An aliquot of each sample was taken for silicic acid analysis every hour and the BSi content was 


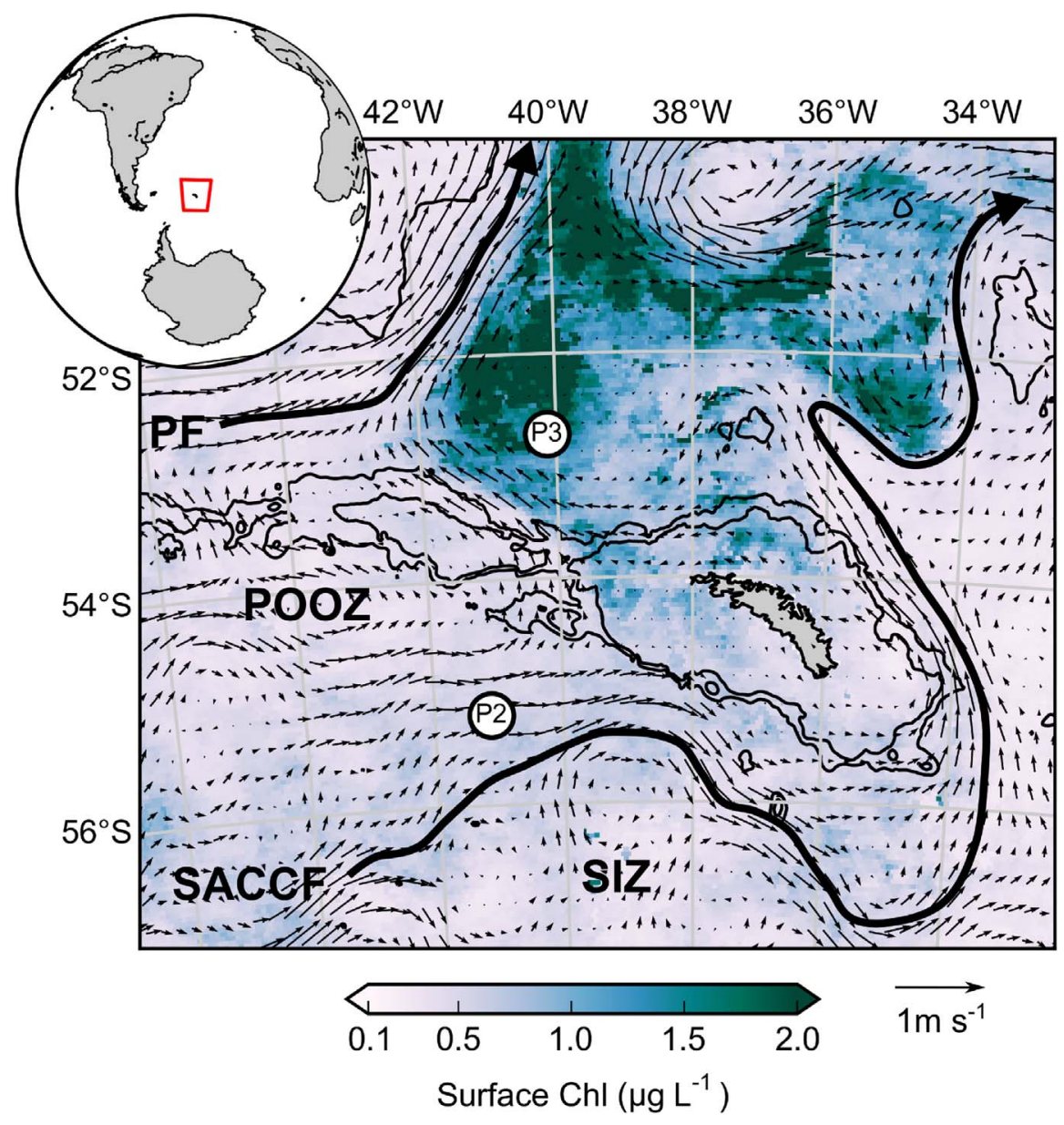

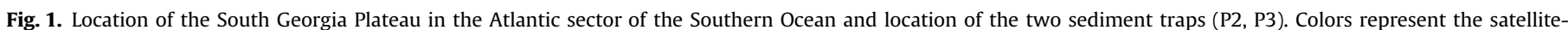

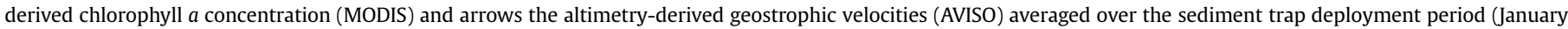

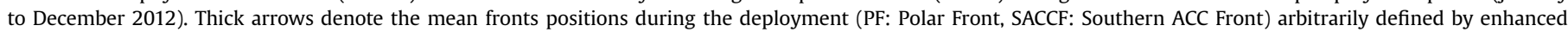

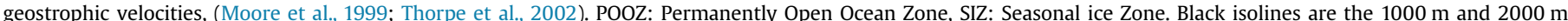
isobaths. (For interpretation of the references to color in this figure, the reader is referred to the web version of this article.)

estimated from the intercept of the extraction time-series (DeMaster, 1981).

\subsection{Remote sensing and derived oceanographic variables}

Satellite-derived surface chlorophyll $a$ concentration (MODIS Aqua, $4 \mathrm{~km}, 8$-days composite, level 3 product) for the sediment trap deployment period was accessed at http://oceancolor.gsfc. nasa.gov/cms/. Altimetry-derived geostrophic velocities (AVISO MADT, $1 / 4^{\circ}$, daily product) were extracted at http://www.aviso.al timetry.fr/. For sea surface temperature (SST) data, the NOAA $1 / 4^{\circ}$ daily Optimum Interpolation Sea Surface Temperature (OISST) was accessed at http://www.esrl.noaa.gov/psd/data/gridded/data.noaa. oisst.v2.html (Reynolds et al., 2002). Time series of chlorophyll $a$ concentration and SST were calculated by averaging the data in a $100 \mathrm{~km}$ radius centered on each sediment trap location. Averages of chlorophyll a concentration and geostrophic velocities were calculated for the sediment trap deployment period of January to December 2012 (Fig. 1).

\subsection{Diatom enumeration, identification and biomass}

Diatom enumeration and identification was performed using a biological counting technique that does not include any chemical treatment before counting (Salter et al., 2012) and thereby allows the separate enumeration of full and empty cells (Rembauville et al., 2015a). A 1/8 aliquot of each sample was gently homogenized and $2 \mathrm{~mL}$ withdrawn and diluted in a final volume of $20 \mathrm{~mL}$ of artificial seawater (salinity=34 PSU). A modified pipette tip with a large aperture was used to avoid breakage of larger species such as Thalassiothrix antarctica. The diluted sample was placed in a Sedgewick-Rafter counting chamber (Pyser-SGI S52, $1 \mathrm{~mL}$ volume). One quarter to one half of the chamber (depending on diatom abundance) was observed with an inverted microscope with phase contrast (Olympus IX70) at $400 \times$ magnification.

Diatoms were identified to the lowest possible taxonomic level following Hasle and Syvertsen (1997). The relatively low magnification imposed by the counting technique and presence of organic material occasionally obscuring the valve face limited species-level identification for some taxa. Consequently certain species were classified as follows: Fragilariopsis separanda and Fragilariopsis rhombica were grouped as Fragilariopsis separanda/rhombica; all the Pseudo-nitzschia species (mainly Pseudo-nitzschia lineola and Pseudo-nitzschia heimii) were grouped as Pseudo-nitzschia spp.; the genera Haslea and Pleurosigma were grouped as Pleurosigma; species of the genera Banquisia and Manguinea and Membraneis challengeri and Membraneis imposter were grouped as Membraneis. Unidentifiable centric species $<20 \mu \mathrm{m}$ and large centric species were denominated as Small centric $(<20 \mu \mathrm{m})$ and Large centric ( $>20 \mu \mathrm{m})$, respectively. This arbitrary size classification was chosen to differentiate small centric species, typically attributable to the Thalassiosira genus, from genera such as 
Table 1

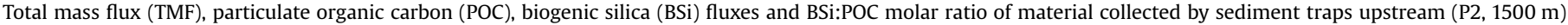
and downstream (P3, $2000 \mathrm{~m})$ of South Georgia.

\begin{tabular}{|c|c|c|c|c|c|c|}
\hline \multirow[t]{2}{*}{ Site } & \multicolumn{2}{|c|}{ Cup collection period (2012) } & \multirow{2}{*}{$\frac{\text { TMF }}{\left(\mathrm{mg} \mathrm{m}^{-2} \mathbf{d}^{-1}\right)}$} & \multirow{2}{*}{$\frac{\text { POC }}{\left(\mu \mathrm{mol} \mathrm{m} \mathbf{~ m}^{-2} \mathbf{d}^{-1}\right)}$} & \multirow{2}{*}{ 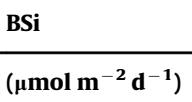 } & \multirow{2}{*}{$\frac{\text { BSi:POC }}{(\mathrm{mol}: \mathrm{mol})}$} \\
\hline & Opening & Closing & & & & \\
\hline \multirow[t]{12}{*}{ P2 } & $15 / 01$ & $01 / 02$ & 24.1 & 38 & 61 & 1.6 \\
\hline & $01 / 02$ & $15 / 02$ & 8.3 & 40 & 25 & 0.6 \\
\hline & $15 / 02$ & $01 / 03$ & 49.7 & 172 & 267 & 1.5 \\
\hline & $01 / 03$ & $01 / 04$ & 60.7 & 101 & 289 & 2.9 \\
\hline & $01 / 04$ & $01 / 05$ & Lost & & & \\
\hline & $01 / 05$ & $01 / 06$ & 17.5 & 205 & 83 & 0.4 \\
\hline & $01 / 06$ & $01 / 07$ & 13.8 & 84 & 18 & 0.2 \\
\hline & $01 / 07$ & $01 / 08$ & Lost & & & \\
\hline & $01 / 08$ & $01 / 09$ & 10.1 & 78 & 26 & 0.3 \\
\hline & $01 / 09$ & $01 / 10$ & 9.7 & 97 & 73 & 0.8 \\
\hline & $01 / 10$ & $01 / 11$ & Lost & & & \\
\hline & $01 / 11$ & $01 / 12$ & 58.2 & 174 & 606 & 3.5 \\
\hline \multirow[t]{12}{*}{ P3 } & $15 / 01$ & $01 / 02$ & 146.0 & 904 & 765 & 0.8 \\
\hline & $01 / 02$ & $15 / 02$ & 42.5 & 164 & 191 & 1.2 \\
\hline & $15 / 02$ & $01 / 03$ & 22.3 & 73 & 60 & 0.8 \\
\hline & $01 / 03$ & $01 / 04$ & 25.0 & 156 & 145 & 0.9 \\
\hline & $01 / 04$ & $01 / 05$ & 9.5 & 86 & 20 & 0.2 \\
\hline & $01 / 05$ & $01 / 06$ & 9.0 & 65 & 18 & 0.3 \\
\hline & $01 / 06$ & $01 / 07$ & 8.9 & 46 & 10 & 0.2 \\
\hline & $01 / 07$ & $01 / 08$ & 15.1 & 70 & 17 & 0.3 \\
\hline & $01 / 08$ & $01 / 09$ & Lost & & & \\
\hline & $01 / 09$ & $01 / 10$ & 17.8 & 110 & 44 & 0.4 \\
\hline & $01 / 10$ & $01 / 11$ & 39.3 & 90 & 349 & 3.9 \\
\hline & $01 / 11$ & $01 / 12$ & 70.3 & 92 & 344 & 3.7 \\
\hline
\end{tabular}

Azpeitia and Actinocyclus comprising the large centric species. All of the whole, intact and recognizable frustules were counted (Supplementary Fig. 1). For each sample, $>300$ cells were counted, except in sample cups \#1, 2, 7 and 8 from the less productive site P2 where only $\sim 100$ cells were counted. Full and empty cells were enumerated separately (e.g. Assmy et al., 2013; Rembauville et al., 2015a). We considered cells as full when plasts were clearly visible and intact (Supplementary Fig. 1). The empty:full export ratio of a given species was defined as the ratio of empty cells to full cells following integration over the complete sediment trap record. Although broken frustules and debris were present (Supplementary Fig. 1), they were not enumerated in the samples. We estimate that the relative abundance of broken frustules is $<15 \%$. Diatom export assemblages were compared between the two sites using Shannon's diversity index $\left(H^{\prime}=\sum_{i=1}^{n} p_{i} \ln \left(p_{i}\right)\right.$, where $n$ is the total number of species and $p_{i}$ the proportion of individuals of species $i)$ and Pielou's evenness index $\left(J^{\prime}=H^{\prime} / H_{\text {max }}^{\prime}\right.$, where $H_{\text {max }}^{\prime}$ is the maximal possible value of $H^{\prime}$, equal to $\left.\ln (\mathrm{n})\right)$. Both indexes were calculated on total (empty and full) cell numbers following integration over the complete sediment trap record.

Full diatom fluxes were converted to carbon fluxes using previously published species-specific biomass values for diatoms in the vicinity of the Kerguelen Plateau (Cornet-Barthaux et al., 2007) which were considered as a good analogue for South Georgia diatom populations. For species not listed in Cornet-Barthaux et al. (2007), 10 representative individuals of each species were measured and biovolume was calculated following Hillebrand et al. (1999). Carbon content was then calculated using the MendenDeuer and Lessard (2000) equation for diatoms $\left(C=0.288 \times V^{0.811}\right)$. For Chaetoceros Hyalochaete resting spores (CRS) and Thalassiosira antarctica resting spores (TRS), 100 randomly selected individuals were measured. Biovolume was calculated and carbon content was estimated using the Kuwata et al. (1993) carbon:volume relationship for CRS and the Menden-Deuer and Lessard (2000) formulation for TRS. The mean carbon content ( \pm standard deviation) was $240 \pm 101 \mathrm{pgC}$ cell $^{-1}$ and $1018 \pm 460 \mathrm{pgC} \mathrm{cell}^{-1}$ for
CRS and TRS, respectively. The list of diatom species and the corresponding carbon content is reported in Table 3 .

To describe the change in diatom assemblage with depth, we compared the annual sediment trap record from P3 with mixed layer diatom assemblage from multiple summer surveys (February 2002, 2003 and January 2005) at the P3 trap location (Korb et al., 2008) and surface sediment diatom assemblage from a core located very close to the trap $\left(42^{\circ} 09.2^{\prime} \mathrm{S}-41^{\circ} 10.7^{\prime} \mathrm{W}, 3760 \mathrm{~m}\right.$, Allen et al., 2005).

\section{Results}

\subsection{Biogeochemical fluxes}

At P2, highest surface chlorophyll $a$ concentration $\left(1.5 \mu \mathrm{g} \mathrm{L}^{-1}\right)$ was observed in February, associated with the highest SST in summer $\left(3.5^{\circ} \mathrm{C}\right.$, Fig. 2a). Chlorophyll $a$ concentration remained low in spring ( $<1 \mu \mathrm{g} \mathrm{L}^{-1}$ from October to December) when SST increased from 0 to $2{ }^{\circ} \mathrm{C}$. At P3, SST followed the same seasonal signal but was $1^{\circ} \mathrm{C}$ warmer. Chlorophyll a concentration was close to P2 values in summer (1.5-2 $\left.\mu \mathrm{g} \mathrm{L}^{-1}\right)$ but was much higher in spring, reaching values $>6 \mu \mathrm{g} \mathrm{L}^{-1}$ in December.

POC fluxes at P2 were $<0.2 \mathrm{mmol} \mathrm{m}^{-2} \mathrm{~d}^{-1}$ throughout the year, with the highest value observed in May (Table 1 and Fig. 2b). At P3, POC fluxes were highest at the beginning of the sediment trap record in January $\left(0.9 \mathrm{mmol} \mathrm{m}^{-2} \mathrm{~d}^{-1}\right)$ and $<0.2 \mathrm{mmol} \mathrm{m}^{-2} \mathrm{~d}^{-1}$ for the remainder of the year. POC export integrated across the sediment trap deployment record was $\sim 1.7$ times greater at P3 compared to P2 (40.6 vs. $26.4 \mathrm{mmol} \mathrm{m}^{-2}$, Table 2). At P2, the highest BSi flux of $0.6 \mathrm{mmol} \mathrm{m}^{-2} \mathrm{~d}^{-1}$ was observed in spring (November), and decreased in summer (February to March) to $0.3 \mathrm{mmol} \mathrm{m}^{-2} \mathrm{~d}^{-1}$ (Table 1 and Fig. 2c). BSi fluxes were $<0.1 \mathrm{mmol} \mathrm{m}^{-2} \mathrm{~d}^{-1}$ the remaining of the year. At P3, the highest BSi flux of $0.8 \mathrm{mmol} \mathrm{m}^{-2} \mathrm{~d}^{-1}$ was concomitant with the highest POC flux at the end January. Winter values (April to 
a

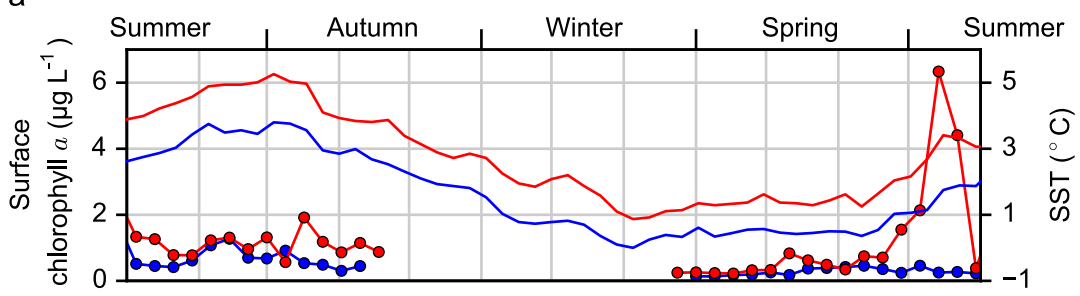

b

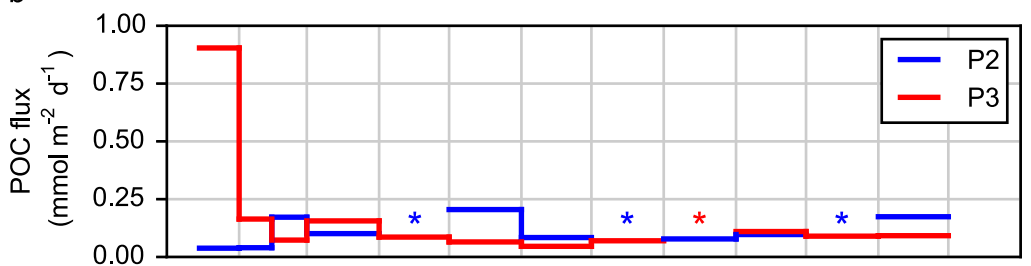

C

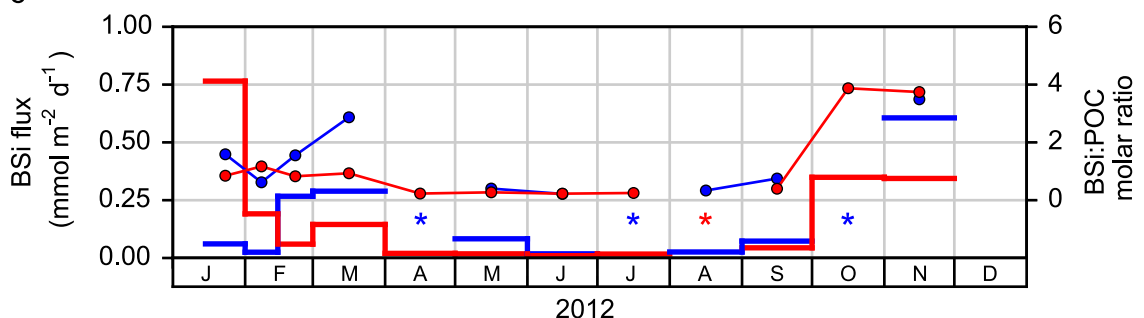

Fig. 2. Oceanographic parameters and biogeochemical fluxes. (a) Satellite-derived surface chlorophyll $a$ (dots) and sea surface temperature (SST, continuous lines) averaged over an area with a $100 \mathrm{~km}$ radius centered on P2 (blue) and P3 (red). (b) Particulate organic carbon (POC) fluxes collected by sediment traps at P2 (1500 m, blue) and P3 $(2000 \mathrm{~m}$, red). (c) Biogenic silica (BSi) fluxes (bold lines) and BSi:POC ratio (dots). Asterisks denote missing cups. (For interpretation of the references to color in this figure legend, the reader is referred to the web version of this article.)

Table 2

Annually integrated fluxes of particulate organic carbon (POC), biogenic silica (BSi) and corresponding BSi:POC molar ratio. Fraction of total empty diatoms, diversity (Shannon's $\mathrm{H}^{\prime}$ ) and evenness (Pielou's $\mathrm{J}^{\prime}$ ) indexes and contribution of each vector to measured carbon fluxes.

\begin{tabular}{|c|c|c|c|c|c|c|c|c|c|c|}
\hline \multirow[t]{2}{*}{ Site } & \multicolumn{4}{|c|}{ Annual flux ( $\mathrm{mmol} \mathrm{m}^{-2}$ or $\mathrm{g} \mathrm{m}^{-2}$ ) } & \multirow{2}{*}{$\begin{array}{l}\text { BSi:POC raw (mol: } \\
\text { mol) }\end{array}$} & \multirow[t]{2}{*}{ Empty diatom (\%) } & \multirow[t]{2}{*}{$\mathbf{H}^{\prime}$} & \multirow[t]{2}{*}{$\mathbf{J}^{\prime}$} & \multicolumn{2}{|c|}{ Contribution to measured POC fluxes (\%) } \\
\hline & POC raw & POC interpolated & BSi raw & BSi interpolated & & & & & Diatom resting spores & Other diatoms \\
\hline \multirow[t]{2}{*}{ P2 } & 26.4 & 35.8 & 38.6 & 55.2 & 1.5 & 91.1 & 1.97 & 0.59 & 0 & 1.9 \\
\hline & 0.32 & 0.46 & 2.59 & 3.71 & & & & & & \\
\hline \multirow[t]{2}{*}{ P3 } & 40.6 & 43.3 & 45.5 & 46.4 & 1.1 & 51.5 & 1.70 & 0.48 & 41.7 & 3.9 \\
\hline & 0.49 & 0.52 & 3.06 & 3.12 & & & & & & \\
\hline
\end{tabular}

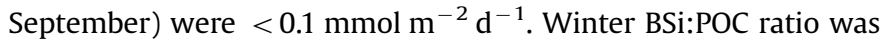
similar at P2 and P3 with low values $<0.5$. The BSi:POC ratio in spring was also similar at the two sites with the highest values observed (3.5-4) in October and November. The main difference between the two sites was in summer, when values of 1.5-3 were observed at P2 whereas the BSi:POC ratio remained $\sim 1$ at P3. The integrated BSi fluxes were lower at P2 than P3 (38.6 versus $45.5 \mathrm{mmol} \mathrm{m}^{-2}$, Table 2) and the annual BSi:POC ratio was higher at P2 (1.5 versus 1.1 ).

\subsection{Diatom fluxes and contribution to carbon fluxes}

At P2, the total diatom flux showed two peaks: the first occurring in summer $\left(3.5 \times 10^{6}\right.$ cell $\left.\mathrm{m}^{-2} \mathrm{~d}^{-1}\right)$ and a second in the following spring $\left(7 \times 10^{6}\right.$ cell $\mathrm{m}^{-2} \mathrm{~d}^{-1}$, Fig. 3a). During winter total diatom fluxes were $<1 \times 10^{6}$ cell $\mathrm{m}^{-2} \mathrm{~d}^{-1}$. Diatom fluxes in spring (November) were characterized by Fragilariopsis kerguelensis (39\% of total cells), Fragilariopsis separanda/rhombica (50\%), Thalassiosira lentiginosa (12\%), Pseudo-nitzschia spp. (10\%) and Dactyliosolen antarcticus (2\%). Summer fluxes contained mainly $F$. kerguelensis (41\% of total cells), Thalassionema nitzschioides (16\%), and Thalassiosira gracilis (7\%, Fig. 3b-h). When integrated over the deployment period, empty diatoms constituted $91.1 \%$ of the total diatom flux at P2 (Table 2). F. kerguelensis dominated ( $>40 \%$ ) the empty, full and total diatom export assemblage (Table 3). Almost all species were preferentially exported as empty cells (empty:full ratio $>1$ ) with the exception of Eucampia antarctica var. antarctica and Navicula sp. that exhibited empty:full ratios close to 1 (Table 3).

At P3, total diatom flux displayed highest values in spring (November) and summer (January). The highest flux of $6 \times 10^{7}$ cell $\mathrm{m}^{-2} \mathrm{~d}^{-1}$ observed at the end of January was one order of magnitude higher than the corresponding maxima at P2 (Fig. 4). In spring, the total cell flux of $8 \times 10^{6}$ cell m-2 $\mathrm{d}^{-1}$ was close to that observed at P2 during the same period. Diatom fluxes were dominated by full cells of CRS, mainly exported during one short event in mid January $\left(3.8 \times 10^{7}\right.$ cell $\mathrm{m}^{-2} \mathrm{~d}^{-1}$, Fig. 4b). CRS accounted for $42.7 \%$ of the total diatom export integrated over the complete record at P3 (Table 3). Concomitant to the significant flux of CRS in January (63\% of total cells in this sample), a noticeable export peak of Eucampia antarctica (3\%), Navicula sp. (3\%) and TRS (1\%) was also observed 
a
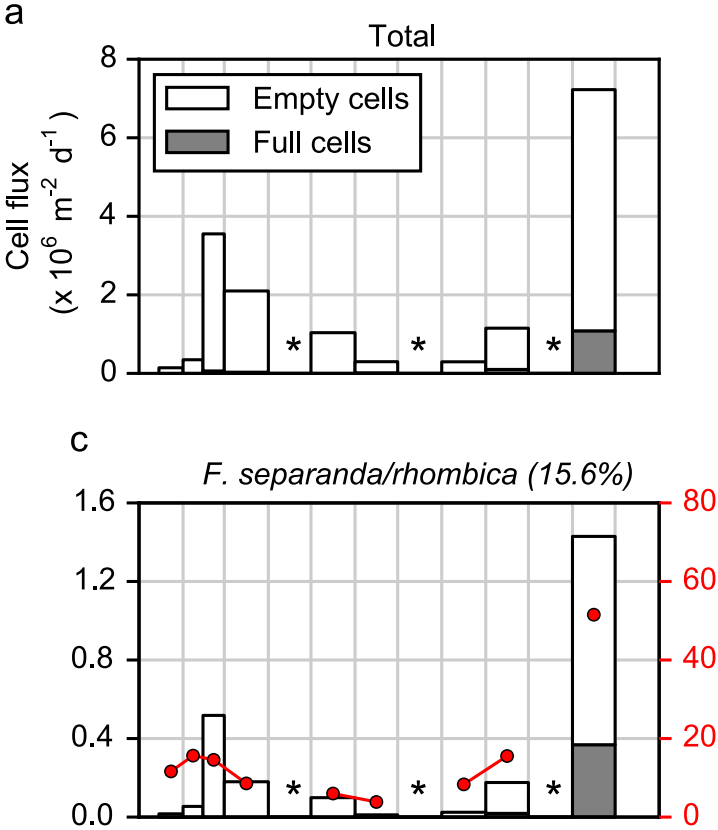

e

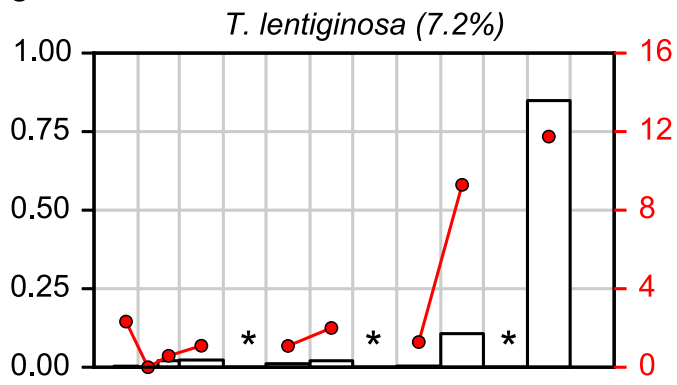

g

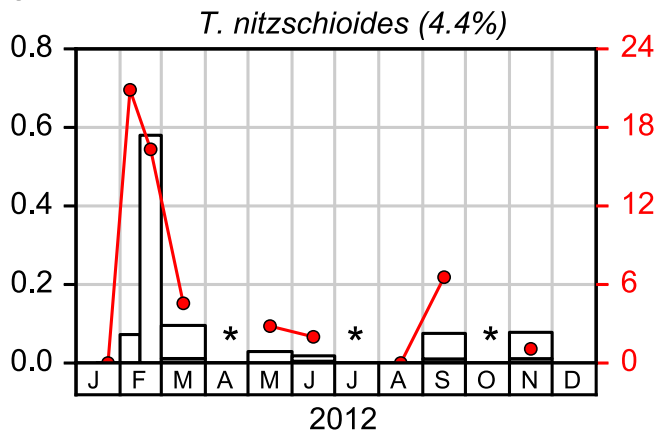

b

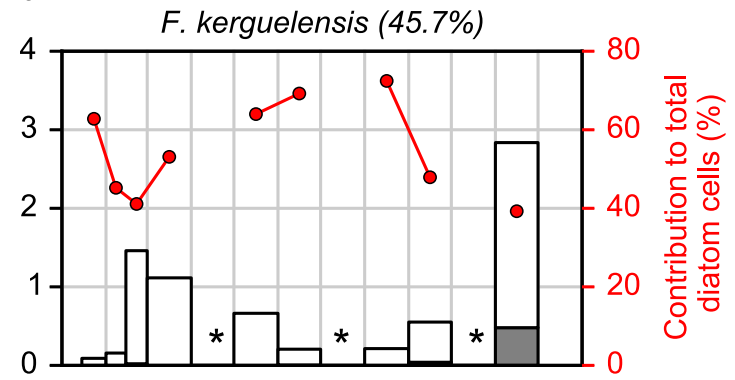

d

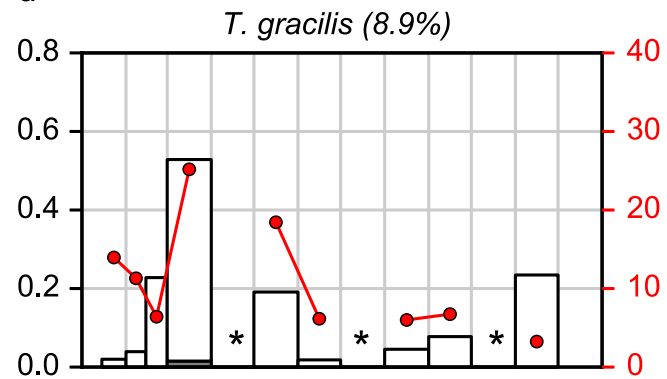

f

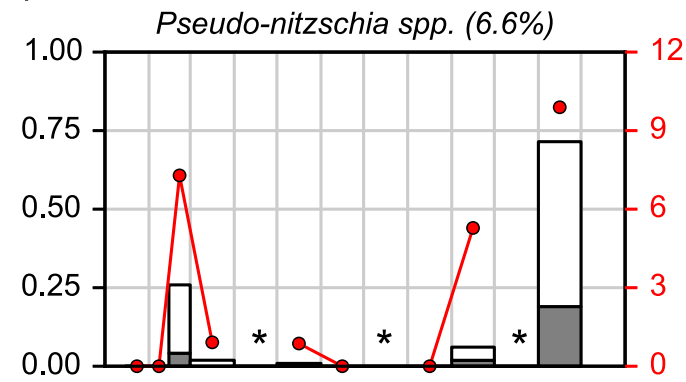

h

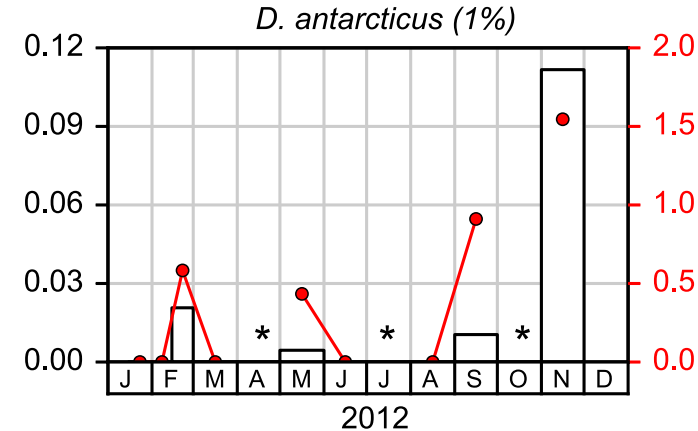

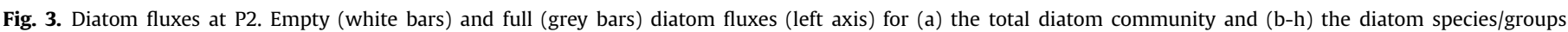

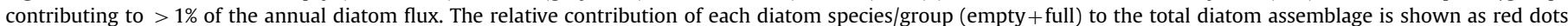

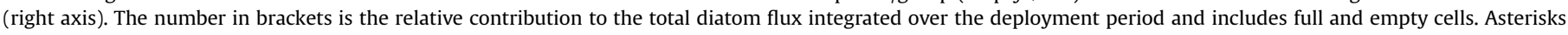
denote missing cups.(For interpretation of the references to color in this figure legend, the reader is referred to the web version of this article.)

(Fig. 4b, f, g, and 1). However, their relative contribution to annual diatom export was much lower $(<3 \%)$. Some species were observed in both spring and summer such as F. kerguelensis, $T$. nitzschioides, F. separanda/rhombica, Pseudo-nitzschia spp., T. gracilis, and T. lentiginosa (Fig. 4c, d, e, i, j and k). Conversely, other species were observed primarily in summer such as CRS, E. antarctica var. antarctica, Navicula sp. and TRS (Fig. 4b, f, g, and 1).

At P3 approximately half (51.5\%) of the diatoms were exported as empty cells when integrated over the deployment period, lower than the corresponding value at P2 (91\%). The diatom assemblage of full cells at P3 was dominated by CRS (87.9\%, Table 3). Empty cells were mostly represented by F. kerguelensis (55.6\%), followed by T. nitzschioides (15.9\%) and F. separanda/rhombica (5\%) (Table 3). Only CRS were exported with an empty:full ratio $<1$, although $E$. antarctica var. antarctica also showed a comparatively low empty: full ratios (1.8). F. kerguelensis was exported with an empty:full ratio of 10.6, a value similar to the one observed at P2 (Table 3).

At P2, diatoms comprised a minor contribution to measured POC fluxes (1.9\%, Table 2). Conversely, diatoms represented $41.7 \%$ of measured POC fluxes at P3 with CRS alone accounting for $38.6 \%$ of POC flux integrated over the deployment period. At both sites 
Table 3

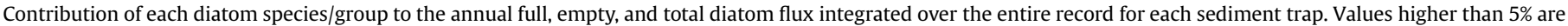
highlighted in bold. Total integrated empty:full ratio. Carbon content used to calculate diatom contribution to carbon export.

\begin{tabular}{|c|c|c|c|c|c|c|c|c|c|}
\hline \multirow[t]{3}{*}{ Species/group } & \multicolumn{4}{|l|}{ P2 } & \multicolumn{4}{|l|}{ P3 } & \multirow[t]{3}{*}{$C$ content $\left(\mathrm{pgC}\right.$ cell $\left.^{-1}\right)$} \\
\hline & \multicolumn{3}{|c|}{ Annual contribution (\%) } & \multirow[t]{2}{*}{ Empty:full } & \multicolumn{3}{|c|}{ Annual contribution (\%) } & \multirow[t]{2}{*}{ Empty:full } & \\
\hline & Full & Empty & Total & & Full & Empty & Total & & \\
\hline $\begin{array}{l}\text { Asteromphalus hookeri } \\
\text { Ehrenberg }\end{array}$ & 0 & 0.4 & 0.4 & & 0 & 0.3 & 0.2 & & $1900^{\mathrm{a}}$ \\
\hline $\begin{array}{l}\text { Asteromphalus hyalinus } \\
\text { Karsten }\end{array}$ & 0 & 0.6 & 0.6 & & 0 & 0.5 & 0.2 & & $365^{\mathrm{a}}$ \\
\hline $\begin{array}{l}\text { Asteromphalus parvulus } \\
\text { Karsten }\end{array}$ & 0 & 0.1 & 0.1 & & 0 & 0.1 & 0.1 & & $365^{\mathrm{a}}$ \\
\hline $\begin{array}{l}\text { Chaetoceros atlanticus } \\
\text { Cleve }\end{array}$ & 0 & 0.9 & 0.8 & & 0 & 0 & 0 & & $217^{\mathrm{b}}$ \\
\hline $\begin{array}{l}\text { Chaetoceros bulbosus } \\
\text { (Ehrenberg) Heiden }\end{array}$ & 0 & 0.2 & 0.1 & & 0 & 0 & 0 & & $222^{\mathrm{a}}$ \\
\hline $\begin{array}{l}\text { Chaetoceros dichaeta } \\
\text { Ehrenberg }\end{array}$ & 0 & 0.5 & 0.5 & & 0 & 0.1 & 0 & & $303^{b}$ \\
\hline Chaetoceros Hyalochaete (spore) group & 0 & 0 & 0 & & 87.9 & 0.1 & 42.7 & 0.0 & $240^{c}$ \\
\hline $\begin{array}{l}\text { Chaetoceros peruvianus } \\
\text { Brightwell }\end{array}$ & 0 & 0 & 0 & & 0 & $<0.1$ & $<0.1$ & & $356^{\mathrm{b}}$ \\
\hline $\begin{array}{l}\text { Corethron inerme } \\
\text { Karsten }\end{array}$ & 0 & 0.9 & 0.8 & & 0 & 1.6 & 0.8 & & $1097^{\mathrm{a}}$ \\
\hline $\begin{array}{l}\text { Corethron pennatum } \\
\text { (Grunow) Ostenfeld }\end{array}$ & 0 & 1.0 & 0.9 & & 0 & 0.6 & 0.3 & & $1097^{a}$ \\
\hline Coscinodiscus group & 0 & 0 & 0 & & 0 & $<0.1$ & $<0.1$ & & $244^{\mathrm{a}}$ \\
\hline $\begin{array}{l}\text { Dactyliosolen antarcticus } \\
\text { Castracane }\end{array}$ & 0 & 1.1 & 1.0 & & 0 & 0.4 & 0.2 & & $700^{\mathrm{a}}$ \\
\hline $\begin{array}{l}\text { Eucampia antarctica var. antarctica } \\
\text { (Castracane) Mangin }\end{array}$ & 1.9 & 0.2 & 0.3 & 1.0 & 1.5 & 2.6 & 2.1 & 1.8 & $416^{\mathrm{a}}$ \\
\hline $\begin{array}{l}\text { Fragilariopsis kerguelensis } \\
\text { (O'Meara) Hustedt }\end{array}$ & 42.4 & 46.0 & 45.7 & 11.2 & 5.6 & 55.6 & 31.4 & 10.6 & $158^{a}$ \\
\hline Fragilariopsis separanda/rhombica (group) & 30.7 & 14.2 & 15.6 & 4.7 & 0.2 & $\mathbf{5 . 0}$ & 2.6 & 30.3 & $128^{\mathrm{a}}$ \\
\hline $\begin{array}{l}\text { Guinardia cylindrus } \\
\text { (Cleve) Hasle }\end{array}$ & 0 & 0 & 0 & & 0 & $<0.1$ & $<0.1$ & & $495^{\mathrm{a}}$ \\
\hline Membraneis group & 0 & 0.4 & 0.4 & & 0 & 0.3 & 0.2 & & $3225^{\mathrm{a}}$ \\
\hline Navicula sp. & 2.7 & 0.2 & 0.4 & 0.8 & 0.8 & 2.8 & 1.8 & 3.5 & $126^{\mathrm{a}}$ \\
\hline $\begin{array}{l}\text { Odontella weissflogii } \\
\text { (Grunow) Grunow }\end{array}$ & 0 & 0.3 & 0.3 & & 0 & 0.9 & 0.5 & & $1939^{\mathrm{a}}$ \\
\hline Pleurosigma group & 0 & 0.5 & 0.5 & & 0 & 0.8 & 0.4 & & $469^{a}$ \\
\hline $\begin{array}{l}\text { Proboscia alata } \\
\text { (Brightwell) Sundström }\end{array}$ & 0 & 0.6 & 0.6 & & 0 & 0.1 & 0.1 & & $3686^{\mathrm{a}}$ \\
\hline $\begin{array}{l}\text { Proboscia inermis } \\
\text { (Castracane) Jordan \& Ligowski }\end{array}$ & 0 & 0.8 & 0.7 & & 0 & 0.1 & 0.1 & & $2898^{a}$ \\
\hline $\begin{array}{l}\text { Proboscia truncata } \\
\text { (Karsten) Nöthig \& Ligowski }\end{array}$ & 0 & 0 & 0 & & 0 & $<0.1$ & $<0.1$ & & $2898^{\mathrm{a}}$ \\
\hline Pseudo-nitzschia spp. group & 18.2 & 5.4 & 6.6 & 3.1 & 0.7 & 2.4 & 1.6 & 3.7 & $127^{\mathrm{a}}$ \\
\hline $\begin{array}{l}\text { Rhizosolenia antenata } f \text {. semispina } \\
\text { Sundström }\end{array}$ & 0 & 0.4 & 0.4 & & 0 & 0.2 & 0.1 & & $1382^{a}$ \\
\hline $\begin{array}{l}\text { Rhizosolenia chunii } \\
\text { Karsten }\end{array}$ & 0 & 0.7 & 0.6 & & 0 & 0.1 & 0.1 & & $1382^{\mathrm{a}}$ \\
\hline $\begin{array}{l}\text { Rhizosolenia simplex } \\
\text { Karsten }\end{array}$ & 0 & 0.4 & 0.3 & & 0 & 0 & 0 & & $1382^{\mathrm{a}}$ \\
\hline $\begin{array}{l}\text { Rhizosolenia styliformis } \\
\text { Brightwell }\end{array}$ & 0 & 0 & 0 & & 0 & 0.1 & 0.1 & & $1382^{a}$ \\
\hline $\begin{array}{l}\text { Thalassionema nitzschioides } \\
\text { (Grunow) Mereschkowsky }\end{array}$ & 3.0 & 4.5 & 4.4 & 15.4 & 1.4 & 15.9 & 8.9 & 11.8 & $30^{\mathrm{a}}$ \\
\hline Thalassiosira antarctica (spore) & 0 & 0 & 0 & & 1.7 & 0.4 & 1.0 & & $1018^{\mathrm{b}}$ \\
\hline $\begin{array}{l}\text { Thalassiosira gracilis } \\
\text { Karsten Hustedt }\end{array}$ & 1.3 & 9.6 & 8.9 & 78.9 & 0 & 2.5 & 1.3 & 122.4 & $93^{a}$ \\
\hline $\begin{array}{l}\text { Thalassiosira lentiginosa } \\
\text { (Janisch) Fryxell }\end{array}$ & 0 & 7.9 & 7.2 & & 0.1 & 2.0 & 1.1 & 20.0 & $3119^{a}$ \\
\hline $\begin{array}{l}\text { Thalassiosira tumida } \\
\text { (Janisch) Hasle }\end{array}$ & 0 & 0 & 0 & & 0 & 0 & 0 & & $379^{\mathrm{a}}$ \\
\hline $\begin{array}{l}\text { Thalassiotrix antarctica } \\
\text { Schimper }\end{array}$ & 0 & 0.7 & 0.6 & & 0 & 0.6 & 0.3 & & $3556^{\mathrm{a}}$ \\
\hline Small centric $(<20 \mu \mathrm{m})$ group & 0 & 0.7 & 0.6 & & 0.1 & 3.2 & 1.7 & 59.0 & $93^{a}$ \\
\hline Large centric ( $>20 \mu \mathrm{m})$ group & 0 & 0.7 & 0.7 & & 0 & 0.4 & 0.2 & 10.4 & $365^{\mathrm{a}}$ \\
\hline
\end{tabular}

a Species-specific biomass taken from Cornet-Barthaux et al. (2007).

${ }^{\mathrm{b}}$ Individuals were measured in the sediment trap samples. Biovolume was calculated from Hillebrand et al. (1999) and carbon:volume relationship from Menden-Deuer and Lessard (2000) was applied.

${ }^{\mathrm{c}}$ Individuals were measured in the sediment trap samples. Biovolume was calculated from Hillebrand et al. (1999) and carbon:volume relationship from Kuwata et al. (1993) was applied. 

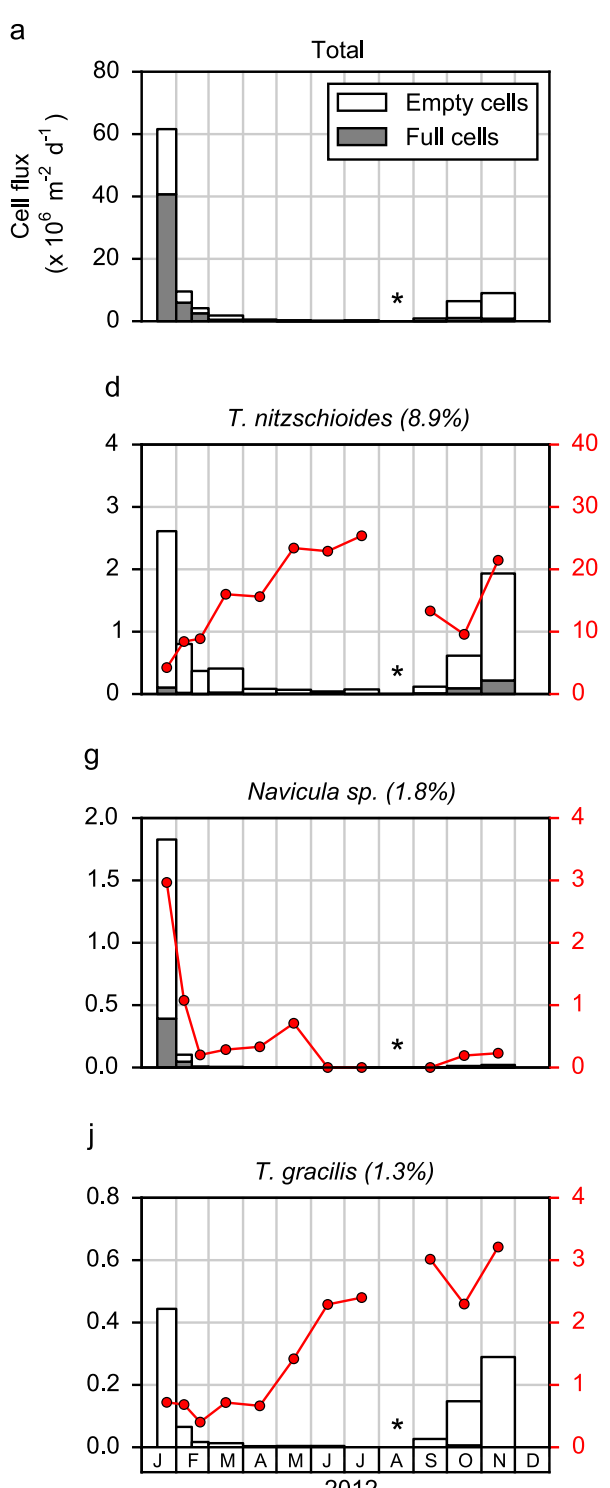

b

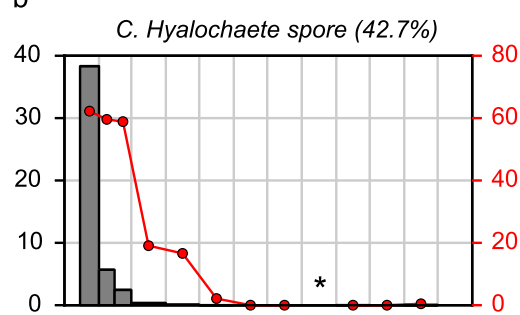

e

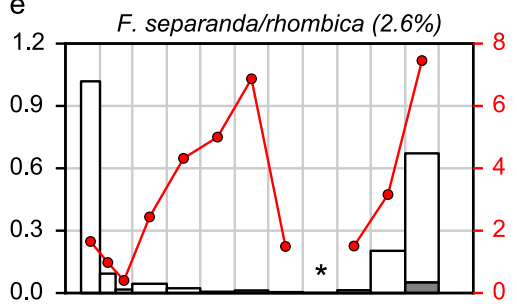

$\mathrm{h}$

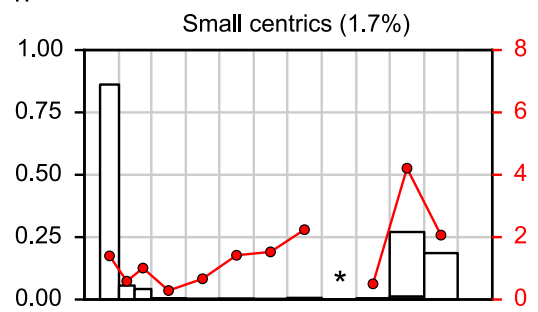

k

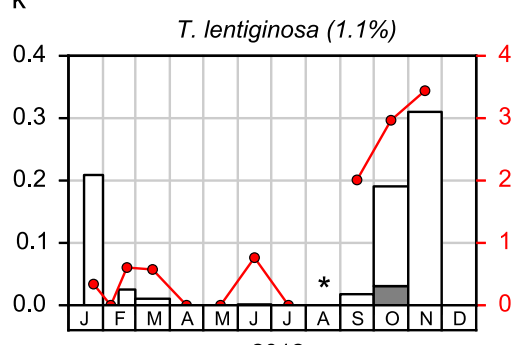

$c$

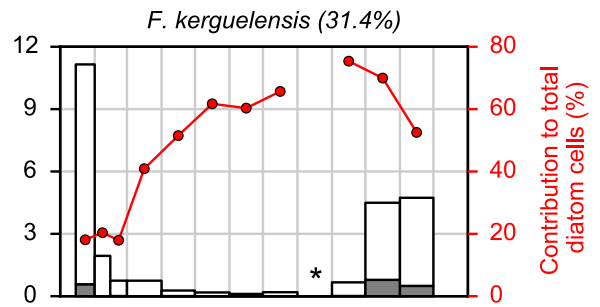

f
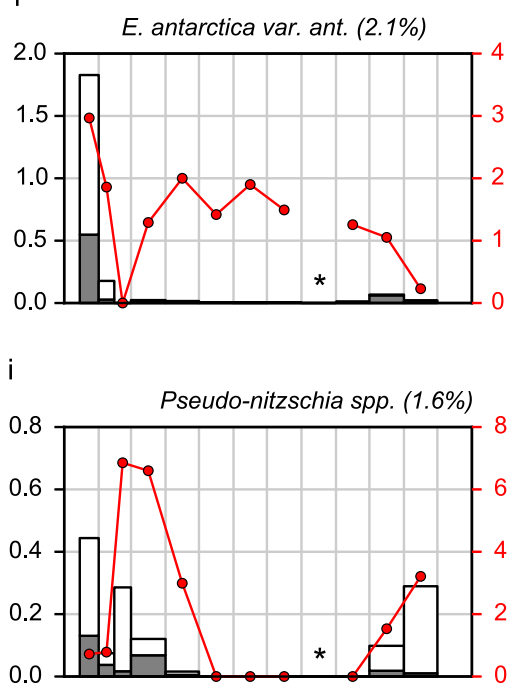

I

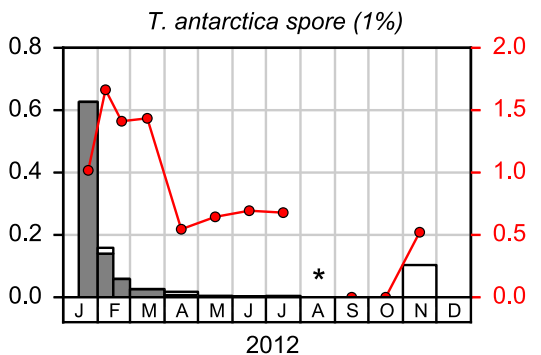

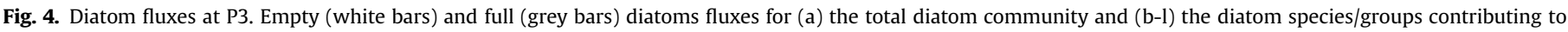

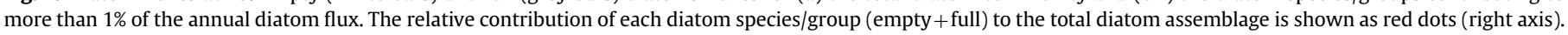

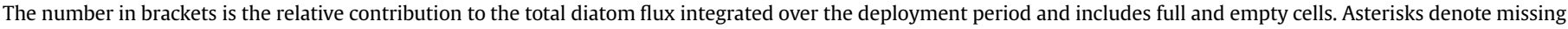
cups. (For interpretation of the references to color in this figure legend, the reader is referred to the web version of this article.)

diatom vegetative stages accounted for a low proportion of POC flux, amounting to $3.9 \%$ at P3 and $1.9 \%$ at P2 (Table 2).

\subsection{Change in diatom assemblages through the water column}

At P3, the mean summer mixed layer diatom assemblages (Korb et al., 2008) are dominated by F. kerguelensis (30\%), followed by Pseudo-nitzschia (20\%) and C. Hyalochaete vegetative stage (10\%, Fig. 5). Between the mixed layer and the sediment trap depth $(2000 \mathrm{~m})$ there are notable decreases in the contribution of Pseudo-nitzschia (20-2\%), Thalassiothrix antarctica (10-1\%) and E. antarctica (8-2.5\%). Conversely, F. kerguelensis relative abundance is similar between the mixed layer and the sediment trap depth (30\%), while the contribution of C. Hyalochaete increases (11-42\%) and is present as resting spores in the trap samples. In surface sediments (Allen et al., 2005), CRS represents $80 \%$ of the diatom assemblage, followed by F. kerguelensis (10\%) and TRS (3\%).

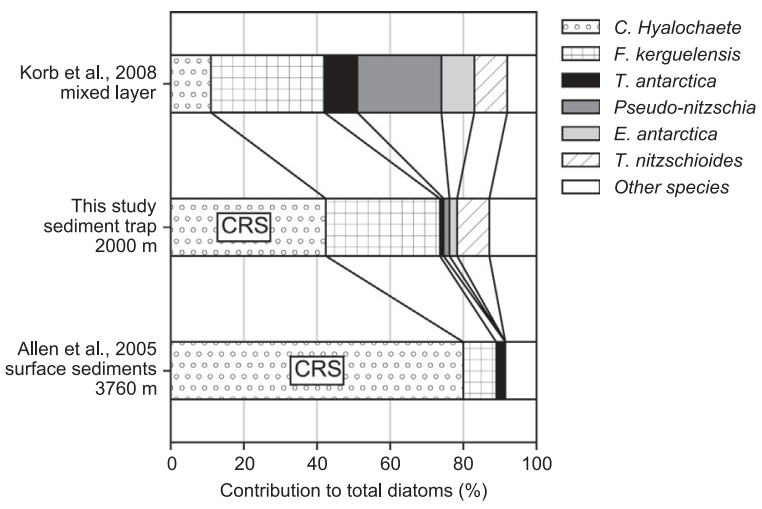

Fig. 5. Evolution of diatom assemblages with depth at P3. Mixed layer data from Korb et al. (2008) are summer averages from February 2002, 2003 and January 2005. Chaetoceros Hyalochaete is present as vegetative stage in the mixed layer and as resting spore (CRS: Chaetoceros Hyalochaete resting spore) in the sediment trap and surface sediment (Allen et al., 2005) assemblages. 


\section{Discussion}

\subsection{Magnitude of particle fluxes}

POC export at station P3 is higher than that observed at station P2 (40.6 $\mathrm{mmol} \mathrm{m}^{-2} \mathrm{yr}^{-1}$ vs. $26.4 \mathrm{mmol} \mathrm{m}^{-2} \mathrm{yr}^{-1}$ ). The omission of flux data from sample cups lost during recovery introduces some uncertainty in equating the integrated POC fluxes to annual values. If the missing values are estimated by linear interpolation (affecting the mean value of two windowing samples to the missing sample) resulting POC export is still higher at P3 and the annual BSi:POC ratio remains similar (Table 2). The missing samples are from a period of low background flux with no notable surface chlorophyll $a$ features (Fig. 2). Consequently we decided not to include the linear interpolation of missing samples and present integrated fluxes of chemical and biological constituents as a conservative approximation of annual flux.

At P3, the sediment trap deployment location is positioned in the center of a cyclonic circulation feature originating from the northern South Georgia shelf (Meredith et al., 2003). The area downstream of South Georgia is fertilized by continuous benthic iron supply from the South Georgia shelf system, resulting in higher dissolved iron concentration when compared to the waters upstream of the island $(0.3 \mathrm{nM}$ versus $<0.05 \mathrm{nM}$ in spring, Nielsdóttir et al., 2012). This natural iron fertilization mechanism has been suggested to support the large and recurrent phytoplankton blooms observed downstream of South Georgia (Fig. 1, Ward et al., 2002; Borrione and Schlitzer, 2013). The regional differences we report in deep-ocean POC fluxes at P2 and P3 are therefore consistent with the varying levels of chlorophyll $a$ biomass observed around South Georgia resulting from differences in iron supply.

Deep-ocean POC fluxes at the productive P3 site lag the strong surface chlorophyll $a$ peak $\left(6 \mu \mathrm{g} \mathrm{L}^{-1}\right)$ by one month and exhibit no notable peaks in the time preceding surface biomass maxima. Time lags of 1-2 month between production and export have been observed previously in the Southern Ocean (Honjo et al., 2000; Buesseler et al., 2001; Rigual-Hernández et al., 2015a,b). During a shallow sediment trap deployment $(289 \mathrm{~m})$ over the central Kerguelen Plateau (Rembauville et al., 2015b), CRS also dominated carbon export and was exported one month after the surface chlorophyll $a$ peak, a pattern very similar to what we observe at P3 despite a much deeper sediment trap depth (2000 m). Highest BSi: POC ratio was observed in spring (September/October) at both sites. Very similar patterns in export stoichiometry have been observed in other naturally fertilized area of the Southern Ocean and were attributed to changes in the diatom community structure across the season (Rembauville et al., 2015a; Salter et al., 2012).

There are no comparable peaks in either surface biomass ( $<2 \mu \mathrm{g} \mathrm{L}^{-1}$ throughout the year) or deep ocean POC flux at station P2 upstream of South Georgia. Despite strong differences in surface phytoplankton biomass, primarily mediated by iron supply (Nielsclóttir et al., 2012; Borrione and Schlitzer, 2013), the amount of POC reaching the deep-ocean differs by a factor of $<2$ between the two sites. This is consistent with a scenario of enhanced carbon remineralization downstream of South Georgia (Cavan et al., 2015; Le Moigne et al., 2016). The annual POC fluxes observed at South Georgia are remarkably similar $\left(<100 \mathrm{mmol} \mathrm{m}^{-2} \mathrm{yr}^{-1}\right)$ to those measured at other naturally iron-fertilized sites in the Southern Ocean (Salter et al., 2012; Rembauville et al., 2015b). These fluxes are also comparable to the ones recorded during annual deployments of deep sediment traps in other non-fertilized areas of the Permanently Open Ocean Zone (POOZ, $33 \mathrm{mmol} \mathrm{m}^{-2} \mathrm{y}^{-1}$ at $2200 \mathrm{~m}$, Fischer et al., 2002; $35 \mathrm{mmol} \mathrm{m}^{-2} \mathrm{y}^{-1}$ at $1300 \mathrm{~m}$, Tesi et al., 2012; $102 \mathrm{mmol} \mathrm{m}^{-2} \mathrm{y}^{-1}$ at $2000 \mathrm{~m}$, Rigual-Hernández et al., 2015a,b ; $180 \mathrm{mmol} \mathrm{m}^{-2} \mathrm{y}^{-1}$ at $1031 \mathrm{~m}$, Honjo et al., 2000). The homogeneity of the deep ocean POC fluxes, despite contrasted surface primary production, highlights the inverse relationship between primary production and export efficiency in the Southern Ocean (Maiti et al., 2013).

\subsection{Seasonality of diatom fluxes}

The majority of studies examining diatom export fluxes in the Southern Ocean have used a micropaleontological technique, originally developed for sediment samples (Funkhouser and Evitt, 1959). To remove organic and detrital material the micropaleontological technique includes a chemical oxidation step to "clean" and isolate the diatom frustules. This treatment separates all frustules into single valves and may selectively damage and dissolve the frustules of certain species. Furthermore, the micropaleontological technique generally considers broken frustules (Schrader and Gersonde, 1978). In the present study a direct observation of samples was favoured to meet the objective of distinguishing full and empty frustules (e.g. Armand et al., 2008; Assmy et al., 2013; Rembauville et al., 2015a) in order to calculate the relative contribution of different diatom species to total POC flux. The two techniques are likely to give slightly different results (Abrantes et al., 2005; Rembauville et al., 2015a) and therefore the comparison of diatom flux data between studies must take into account these different analytical approaches.

Despite the methodological considerations described above, a comparison of diatom export fluxes from different oceanographic zones reveals quite consistent patterns. The highest total diatom flux at P2 equals $1.4 \times 10^{7}$ valves $\mathrm{m}^{-2} \mathrm{~d}^{-1}$ (frustules converted to valves with a factor 2 ), similar to previous findings in low productivity waters of the POOZ $\left(\sim 10^{7}\right.$ valves $\mathrm{m}^{-2} \mathrm{~d}^{-1}$, Abelmann and Gersonde, 1991; Grigorov et al., 2014). At P3, highest total diatom flux is one order of magnitude higher with $1.2 \times 10^{8}$ valves $\mathrm{m}^{-2} \mathrm{~d}^{-1}$. This flux is comparable to the $2.4 \times 10^{8}$ valves $\mathrm{m}^{-2} \mathrm{~d}^{-1}$ found in a shallower $(289 \mathrm{~m})$ sediment trap at the central Kerguelen Plateau (station A3, Rembauville et al., 2015a), and a deep sediment trap (2000 $\mathrm{m})$ also located in the POOZ ( $4 \times 10^{8}$ valves $\mathrm{m}^{-2} \mathrm{~d}^{-1}$, Rigual-Hernández et al., 2015a, b). Despite the high primary production levels at these naturallyfertilized sites (P3 and A3), diatom valve fluxes remain lower than those reported in the Seasonal Ice Zone (SIZ) with fluxes of $\sim 10^{9}$ valves $\mathrm{m}^{-2} \mathrm{~d}^{-1}$ (Suzuki et al., 2001; Pilskaln et al., 2004). These massive diatom export fluxes in the SIZ are attributed to changes in light availability and melt waters input during sea ice retreat that favors production and export of POC by diatoms (Smith and Nelson, 1986; Annett et al., 2009; Romero and Armand, 2010). In addition to iron supply, silicic acid availability also plays an important role in diatom productivity (Mengelt et al., 2001; Poulton et al., 2007). Lower diatom fluxes of $2.5 \times 10^{7}$ valves $\mathrm{m}^{-2} \mathrm{~d}^{-1}$ were observed (Salter et al., 2012) in the iron-fertilized productive waters downstream of Crozet (Polar Frontal Zone, PFZ) and may be explained by the lower silicic acid concentration and higher temperature north of the Polar Front (Pondaven et al., 2000; Whitehouse et al., 2012).

The similarity of diatom export assemblages observed in sediment traps is in stark contrast with the observed differences in surface waters assemblages. In the surface lightly silicified species (e.g. Chaetoceros Hyalochaete, Pseudo-nitzschia spp.) are dominant upstream of South Georgia, compared to more robust and highly silicified species (Corethron pennatum, Thalassiothrix antarctica, Eucampia antarctica var. antarctica) downstream (Korb et al., 2010, 2012). In the sediment traps, with the notable exception of resting spores and neritic species (Chaetoceros Hyalochaete, E. antarctica var. antarctica and Navicula sp.), the diatom species export assemblage is comparable at both sites. The slightly lower evenness 
at P3 (Table 2) reflects the dominant contribution of CRS to the total diatom flux. Fragilariopsis kerguelensis, Pseudo-nitzschia spp., Thalassiosira gracilis, Thalassiosira lentiginosa and Thalassionema nitzschioides are abundant at both sites (Table 3). All of these species (with the exception of Pseudo-nitzschia spp.) are considered to have robust and highly silicified frustules. Preferential grazing pressure on lightly-silicified species in the upper ocean (e.g. Smetacek et al., 2004; Assmy et al., 2013) and mesopelagic BSi dissolution (Nelson et al., 1995; Ragueneau et al., 2000, 2006) may explain the dominance of highly-silicified species to bathypelagic diatom flux assemblages. Additionally, horizontal advection could homogenize variability in the surface signal (Siegel and Deuser, 1997; van Sebille et al., 2015). The absence of Chaetoceros Hyalochaete vegetative stages from the sediment trap record at both sites despite its presence in the mixed layer in summer (Korb et al., 2010,2008 ) could be explained by the preferential dissolution of the weakly silicified vegetative frustules and/or conversion into resting spore below the mixed layer at P3 (Rynearson et al., 2013).

\subsection{Si:C export stoichiometry}

It has been suggested previously that diatom species-specific sensitivity to grazing pressure and the presence of certain life cycle stages can impact the Si:C export stoichiometry through the differential export of full or empty cells (Smetacek et al., 2004; Salter et al., 2012; Assmy et al., 2013). In the South Georgia trap samples resting spores were almost exclusively exported as full cells. Culture experiments suggest CRS are poorly grazed by copepods, and may even lower the grazing rate (Kuwata and Tsuda, 2005), potentially contributing to their export from the mixed layer as full cells. Navicula sp., E. antarctica var. antarctica and Pseudo-nitzschia spp. were exported with relatively low empty:full of $<5$, in good agreement with previous findings from the Kerguelen Plateau (Rembauville et al., 2015a). These species were also associated with highest POC fluxes in the PFZ in the Australian sector of the Southern Ocean (Rigual-Hernández et al., 2015a,b), highlighting their potential role in carbon export.

With the exception of the resting spore export event at the end of summer, the dominance of empty $F$. kerguelensis in spring, autumn and winter at South Georgia and Kerguelen confirms its key role in the silicon pump (Smetacek et al., 2004; Salter et al., 2012; Assmy et al., 2013). The seasonal evolution of the BSi:POC ratio is similar at P2 and P3 (except in summer) and reflects comparable diatom community composition. However, the lower BSi:POC ratio in summer at P3 can be attributed to the sinking of carbon-rich diatom resting spores containing neutral lipids (Doucette and Fryxell, 1983; Kuwata et al., 1993). These findings support an emerging view (Salter et al., 2012; Rembauville et al., 2015a) that the flux of carbon rich resting spores/stages are of particular importance in setting the $\mathrm{Si}: \mathrm{C}$ export stoichiometry characterizing naturally-fertilized island systems in the Southern Ocean.

Certain species that were preferentially exported as full cells at $289 \mathrm{~m}$ at Kerguelen were only found as empty cells at both P2 and P3 sites (Thalassiothrix antarctica, Chaetoceros dichaeta and Proboscia inermis). These species are either very large ( $T$. antarctica, $P$. inermis), or exhibit spiny setae (C. dichaeta), which are thought to confer some protection from grazing (Smetacek et al., 2004). Other processes such as microbial degradation of the cellular content during sinking (Grossart and Ploug, 2001; Twining et al., 2014) might contribute to the high empty:full ratio observed for these species in deeper samples. Alternatively, the more abundant krill population at South Georgia (Atkinson et al., 2008), which is able to feed on larger phytoplankton species (Graníi et al., 1993), might explain the higher empty:full ratio observed for these species when compared to Kerguelen. These findings suggest that differences in upper trophic level ecosystem structure modulate the role a particular diatom species plays in carbon and BSi flux, limiting species-level generalizations between regions.

\subsection{Resting spore formation and carbon transfer to the seafloor}

Resting spores comprising bathypelagic ( $>1500 \mathrm{~m}$ ) flux around South Georgia were present almost entirely as full cells and accounted for $41.7 \%$ of the annual POC flux. Similar observations were made at $289 \mathrm{~m}$ over the Kerguelen Plateau (Rembauville et al., 2015a). These findings suggest that their importance as a POC vector persists throughout the water column. To examine changes in the occurrence of CRS as a function of depth upstream of South Georgia we combined our sediment trap dataset with mixed layer (Korb et al., 2008) and sediment (Allen et al., 2005) assemblage data (Fig. 5). We make these comparisons cautiously for several reasons: (i) mixed layer data are from January and February, averaged over three years (Korb et al., 2008), and are unlikely to represent seasonal integrals of diatom communities, (ii) surface sediments integrate over several years, averaging any inter-annual variability, and (iii) different diatom counting techniques were used. Given the considerations described above these data comparisons should be considered only as a semi-quantitative analysis of the relative importance of CRS at different depth horizons. There is a significant increase in the proportion of Chaetoceros Hyalochaete from the mixed layer to sediment (10$80 \%$ ). Chaetoceros Hyalochaete species were only observed as vegetative stages in the mixed layer and resting spores below $1500 \mathrm{~m}$. This could be due to either (i) resting spore formation had not occurred at the time of the sampling in the Korb et al. (2008, 2010) studies or (ii) resting spore formation occurs below the mixed layer (e.g. Rynearson et al., 2013). The increase in CRS through the mesopelagic and into the sediments supports a scenario whereby they become increasingly important vectors of carbon through selective preservation of their robust frustules.

Considering the significance of resting spores as a deep-ocean carbon vector upstream of South Georgia, it is of interest to assess the factors triggering spore formation. Numerous experimental studies have demonstrated the role of macronutrient and trace metal limitation for resting spore formation in diatoms in laboratory experiments (Garrison, 1981; Sanders and Cibik, 1985; Kuwata et al., 1993; Oku and Kamatani, 1997, Sugie et al., 2010). Chaetoceros Hyalochaete vegetative stages were observed in the summer upstream and downstream of South Georgia (Korb et al., $2010,2008)$, although only present in export assemblages downstream. A difference in nutrient utilization at the two sites could explain the difference level of resting spore formation. It is generally reported that nitrogen limitation is the most important factor driving resting spore formation (McQuoid and Hobson, 1996, Sugie et al., 2008), although these observations were only made for low latitude diatom populations where nitrate is seasonally depleted. In the Southern Ocean, and more specifically south of the Polar Front, nitrate concentration is always $>20 \mu \mathrm{mol} \mathrm{L}^{-1}$ in summer, even in very productive areas (Nielsdóttir et al., 2012; Whitehouse et al., 2012; Blain et al., 2015). It therefore seems unlikely that nitrate limitation can explain the regional differences in resting spore formation.

Downstream of South Georgia, silicic acid drawdown over the summer ranges between 20 and $35 \mu \mathrm{mol} \mathrm{L}^{-1}$ and summer mixed layer values are $<5 \mu \mathrm{mol} \mathrm{L}^{-1}$ (Whitehouse et al., 2000; Nielsdóttir et al., 2012; Whitehouse et al., 2012; Borrione and Schlitzer, 2013). In contrast, upstream of South Georgia mixed layer concentrations remain at $\sim 20 \mu \mathrm{mol} \mathrm{L}^{-1}$ upstream (Korb et al., 2008; Nielsdóttir et al., 2012) despite substantial silicic acid utilization. The P3 site is also characterized by low dissolved iron concentration in the mixed layer in spring $\left(0.06-0.07 \mathrm{nmol} \mathrm{L}^{-1}\right)$ compared to waters below the thermocline $\left(0.25-0.43 \mathrm{nmol} \mathrm{L}^{-1}\right.$ at $\left.1000 \mathrm{~m}\right)$ 
(Nielsclóttir et al., 2012) suggesting a scenario whereby a formerly iron-replete community moves into limitation. The limitation by silicic acid and iron in summer has already been observed in two other naturally-fertilized systems of the Southern Ocean where resting spore formation is an important process for the export of carbon out of the mixed layer: the Crozet Plateau (Salter et al., 2012) and the Kerguelen Plateau (Rembauville et al., 2015a). These data suggest that iron and/or silicic acid limitation in summer might trigger resting spore formation in high latitude diatoms species, although this hypothesis requires further investigations.

\subsection{Possible limitations of the present dataset}

Partitioning carbon export across diatom species vectors is dependent on carbon:volume relationships (e.g. Rynearson et al., 2013), which can exhibit variability among species (MendenDeuer and Lessard, 2000) and life cycle stages (Kuwata et al., 1993). In the present study we tried to minimize this artifact by using species-specific relationships and where necessary distinct values for vegetative and resting stages (for Chaetoceros Hyalochaete and Thalassiosira antarctica). The variability of the biovolume among individuals of a given species and the uncertainty on the carbon:volume relationship result in a coefficient of variation for resting spore carbon content of $40 \%$. This certainly affects the precision of our estimates. However, it is unlikely to alter our main conclusion that Chaetoceros Hyalochaete resting spores contribute to a significant fraction of bathypelagic carbon fluxes downstream of South Georgia.

The calculated diatom contribution to carbon export accounts for $<50 \%$ of the measured carbon flux at P3 and only $2 \%$ at P2. This indicates that flux vectors not quantified here contribute significantly to carbon export at both sites. Faecal pellets (Manno et al., 2015) and/or other plankton groups (e.g. radiolarians Lampitt et al., 2009) are likely to be important components of carbon flux budgets. Nevertheless, we outline that the export of diatom spores makes a significant contribution to POC export at P3. At this same site, annual POC export in 2010 was $\sim 100 \mathrm{mmol} \mathrm{m}^{-2} \mathrm{y}^{-1}$ (Manno et al., 2015), approximately two times higher than what we report for the 2012. This highlight the need to address inter annual variability of deep ocean POC fluxes (e.g. Salter et al., 2010; Nodder et al., 2016) before robust conclusions can be drawn about a particular system.

We associate the BSi:POC ratio with diatom community composition and empty:full cell ratio based on co-occurrence patterns. An accurate partitioning of biogenic silica fluxes amongst diatom species would require knowledge of the BSi content per frustule for different species and these data are currently unavailable (Jungandreas et al., 2012). Additionally, broken frustules and debris, as well as other siliceous plankton (radiolarian, silicoflagellates) were not quantified here and certainly contribute to BSi fluxes (Supplementary Figure 1). However, despite the technical difficulties, partitioning elemental fluxes across species vectors (e.g. Salter et al., 2014; Rembauville et al. 2016) is an important endeavor for establishing the links between biological diversity and biogeochemical fluxes. However, despite the technical difficulties, partitioning elemental fluxes across species vectors (e.g. Salter et al., 2014; Rembauville et al., 2016) is an important endeavor for establishing the links between biological diversity and biogeochemical fluxes.

\section{Conclusion}

Diatom export fluxes over a complete seasonal cycle are now available from the three major naturally iron-fertilized Southern Ocean island systems: South Georgia (this study), Crozet (Salter et al., 2012) and Kerguelen (Rembauville et al., 2015a). Despite strong regional differences in bloom dynamics and sediment trap deployment depths $(289-3160 \mathrm{~m})$, annual POC export is of the same order of magnitude at each site $\left(40-100 \mathrm{mmol} \mathrm{m}^{-2} \mathrm{~d}^{-1}\right)$. A similar mechanism of diatom resting spore formation and subsequent export to depth is observed at all three sites. In the naturally fertilized sites of South Georgia and Kerguelen, partitioning carbon fluxes across diatom species indicates that $40-60 \%$ of annual POC export beneath the mixed layer can be attributed to resting spore-driven export. Furthermore, consistent seasonal patterns of diatom export assemblages emerge from the comparison of these systems that appear to exert significant control on Si: $\mathrm{C}$ export stoichiometry. Silicon-rich fluxes consisting of empty Fragilariopsis species ("silica sinkers") are observed throughout the year with highest relative abundance in winter and spring. Conversely, carbon-rich fluxes are observed in summer and contain resting spores and other species exported with a high proportion of full cells such as Eucampia antarctica var. antarctica, and Navicula sp. ("carbon sinkers"). The selective preservation of the robust resting spore frustules as a function of depth highlights the increasing importance of resting spores as carbon vector into the bathypelagic ocean and ultimately the sediments. They may thus play a critical role in sequestering atmospheric $\mathrm{CO}_{2}$ from these naturally iron fertilized systems over climatically relevant timescales. The exact environmental triggers for resting spore formation, and their subsequent export to depth, requires further investigation.

\section{Acknowledgements}

We are grateful to the officers and crew of the RRS James Clark Ross for their assistance in carrying out marine operations in the Southern Ocean. We thank Sophie Fielding, Peter Enderlain and Gabriele Stowasser for helping with deployment and recovering of sediment traps. This work was supported by the Ecosystems programme at the British Antarctic Survey (Natural Environment Research Council) and the French research programme of INSUCNRS LEFE-CYBER.

\section{Appendix A. Supporting information}

Supplementary data associated with this article can be found in the online version at doi:10.1016/j.dsr.2016.05.002.

\section{References}

Abelmann, A., Gersonde, R., 1991. Biosiliceous particle flux in the Southern Ocean. Mar. Chem. 35, 503-536. http://dx.doi.org/10.1016/S0304-4203(09)90040-8.

Abrantes, F., Gil, I., Lopes, C., Castro, M., 2005. Quantitative diatom analyses-a faster cleaning procedure. Deep Sea Res. Part I: Oceanogr. Res. Pap. 52, 189-198. http://dx.doi.org/10.1016/j.dsr.2004.05.012.

Allen, C.S., Pike, J., Pudsey, C.J., Leventer, A., 2005. Submillennial variations in ocean conditions during deglaciation based on diatom assemblages from the southwest Atlantic. Paleoceanography 20, PA2012. http://dx.doi.org/10.1029/ 2004PA001055.

Annett, A.L., Carson, D.S., Crosta, X., Clarke, A., Ganeshram, R.S., 2009. Seasonal progression of diatom assemblages in surface waters of Ryder Bay, Antarctica. Polar Biol. 33, 13-29. http://dx.doi.org/10.1007/s00300-009-0681-7.

Armand, L.K., Cornet-Barthaux, V., Mosseri, J., Quéguiner, B., 2008. Late summer diatom biomass and community structure on and around the naturally ironfertilised Kerguelen Plateau in the Southern Ocean. Deep Sea Res. Part II: Top. Stud. Oceanogr. 55, 653-676. http://dx.doi.org/10.1016/j.dsr2.2007.12.031.

Assmy, P., Smetacek, V., Montresor, M., Klaas, C., Henjes, J., Strass, V.H., Arrieta, J.M., Bathmann, U., Berg, G.M., Breitbarth, E., Cisewski, B., Friedrichs, L., Fuchs, N., Herndl, G.J., Jansen, S., Krägefsky, S., Latasa, M., Peeken, I., Röttgers, R., Scharek, R., Schüller, S.E., Steigenberger, S., Webb, A., Wolf-Gladrow, D., 2013. Thickshelled, grazer-protected diatoms decouple ocean carbon and silicon cycles in 
the iron-limited Antarctic Circumpolar. Curr. Proc. Natl. Acad. Sci. 110, 20633-20638. http://dx.doi.org/10.1073/pnas.1309345110.

Atkinson, A., Siegel, V., Pakhomov, E.A., Jessopp, M.J., Loeb, V., 2009. A re-appraisa of the total biomass and annual production of Antarctic krill. Deep Sea Res. Part I: Oceanogr. Res. Pap. 56, 727-740. http://dx.doi.org/10.1016/j.dsr.2008.12.007.

Atkinson, A., Siegel, V., Pakhomov, E.A., Rothery, P., Loeb, V., Ross, R.M., Quetin, L.B. Schmidt, K., Fretwell, P., Murphy, E.J., Tarling, G.A., Fleming, A.H., 2008. Oceanic circumpolar habitats of Antarctic krill. Mar. Ecol. Prog. Ser. 362, 1-23. http://dx doi.org/10.3354/meps07498.

Blain, S., Capparos, J., Guéneuguès, A., Obernosterer, I., Oriol, L., 2015. Distributions and stoichiometry of dissolved nitrogen and phosphorus in the iron-fertilized region near Kerguelen (Southern Ocean). Biogeosciences 12, 623-635. http: //dx.doi.org/10.5194/bg-12-623-2015.

Blain, S., Quéguiner, B., Armand, L., Belviso, S., Bombled, B., Bopp, L., Bowie, A., Brunet, C., Brussaard, C., Carlotti, F., Christaki, U., Corbière, A., Durand, I., Ebersbach, F., Fuda, J.-L., Garcia, N., Gerringa, L., Griffiths, B., Guigue, C., Guillerm, C., Jacquet, S., Jeandel, C., Laan, P., Lefèvre, D., Lo Monaco, C., Malits, A., Mosseri, J., Obernosterer, I., Park, Y.-H., Picheral, M., Pondaven, P., Remenyi, T. Sandroni, V., Sarthou, G., Savoye, N., Scouarnec, L., Souhaut, M., Thuiller, D., Timmermans, K., Trull, T., Uitz, J., van Beek, P., Veldhuis, M., Vincent, D., Viollier, E., Vong, L., Wagener, T., 2007. Effect of natural iron fertilization on carbon sequestration in the Southern Ocean. Nature 446, 1070-1074. http://dx.doi.org/ 10.1038 /nature05700.

Blain, S., Tréguer, P., Belviso, S., Bucciarelli, E., Denis, M., Desabre, S., Fiala, M., Martin Jézéquel, V., Le Fèvre, J., Mayzaud, P., Marty, J.-C., Razouls, S., 2001. A biogeochemical study of the island mass effect in the context of the iron hypothesis: Kerguelen Islands Southern Ocean. Deep Sea Res. Part I: Oceanogr. Res. Pap. 48 163-187. http://dx.doi.org/10.1016/S0967-0637(00)00047-9.

Borrione, I., Schlitzer, R., 2013. Distribution and recurrence of phytoplankton blooms around South Georgia, Southern Ocean. Biogeosciences 10, 217-231. http://dx.doi.org/10.5194/bg-10-217-2013.

Boyd, I.L., Arnbom, T.A., Fedak, M.A., 1994. Biomass and energy consumption of the South Georgia population of southern elephant seals, in: Proceedings of Elephant Seals: Population Ecology, Behavior, and Physiology, pp. 98-117.

Boyd, P., Newton, P., 1995. Evidence of the potential influence of planktonic community structure on the interannual variability of particulate organic carbon flux. Deep Sea Res. Part I: Oceanogr. Res. Pap. 42, 619-639. http://dx.doi.org/ 10.1016/0967-0637(95)00017-Z

Boyd, P.W., Newton, P.P., 1999. Does planktonic community structure determine downward particulate organic carbon flux in different oceanic provinces? Deep Sea Res. Part I: Oceanogr. Res. Pap. 46, 63-91. http://dx.doi.org/10.1016/ S0967-0637(98)00066-1.

Buesseler, K.O., Ball, L., Andrews, J., Cochran, J.K., Hirschberg, D.J., Bacon, M.P., Fleer, A., Brzezinski, M., 2001. Upper ocean export of particulate organic carbon and biogenic silica in the Southern Ocean along $170^{\circ} \mathrm{W}$. Deep Sea Res. Part II: Top. Stud. Oceanogr. 48, 4275-4297. http://dx.doi.org/10.1016/S0967-0645(01) 00089-3.

Cavan, E.L., Le Moigne, F.A.C., Poulton, A.J., Tarling, G.A., Ward, P., Daniels, C.J., Fragoso, G., Sanders, R.J., 2015. Zooplankton fecal pellets control the attenuation of particulate organic carbon flux in the Scotia Sea, Southern Ocean. Geophys. Res. Lett. . http://dx.doi.org/10.1002/2014GL062744

Christaki, U., Lefèvre, D., Georges, C., Colombet, J., Catala, P., Courties, C., SimeNgando, T., Blain, S., Obernosterer, I., 2014. Microbial food web dynamics during spring phytoplankton blooms in the naturally iron-fertilized Kerguelen area (Southern Ocean). Biogeosciences 11, 6739-6753. http://dx.doi.org/10.5194/ bg-11-6739-2014.

Collins, M.A., Stowasser, G., Fielding, S., Shreeve, R., Xavier, J.C., Venables, H.J., Enderlein, P., Cherel, Y., Van de Putte, A., 2012. Latitudinal and bathymetric patterns in the distribution and abundance of mesopelagic fish in the Scotia Sea. Deep Sea Res. Part II: Top. Stud. Oceanogr. 59-60, 189-198. http://dx.doi.org/ 10.1016/j.dsr2.2011.07.003 (DISCOVERY 2010: Spatial and Temporal Variability in a Dynamic Polar Ecosystem).

Cornet-Barthaux, V., Armand, L., Quéguiner, B., 2007. Biovolume and biomass estimates of key diatoms in the Southern Ocean. Aquat. Microb. Ecol. 48 295-308. http://dx.doi.org/10.3354/ame048295.

de Baar, H.J.W., Buma, A.G.J., Nolting, R.F., Cadée, G.C., Jacques, G., Tréguer, P., 1990 On iron limitation of the Southern Ocean: experimental observations in the Weddell and Scotia Seas. Mar. Ecol. Prog. Ser. 65, 105-122. http://dx.doi.org 10.3354/meps065105.

de Baar, H.J.W., de Jong, J.T.M., Bakker, D.C.E., Löscher, B.M., Veth, C., Bathmann, U. Smetacek, V., 1995. Importance of iron for plankton blooms and carbon dioxide drawdown in the Southern Ocean. Nature 373, 412-415. http://dx.doi.org/ 10.1038/373412a0.

DeMaster, D.J., 1981. The supply and accumulation of silica in the marine environment. Geochim. Cosmochim. Acta 45, 1715-1732. http://dx.doi.org/ 10.1016/0016-7037(81)90006-5.

Doucette, G.J., Fryxell, G.A., 1983. Thalassiosira antarctica: vegetative and resting stage chemical composition of an ice-related marine diatom. Mar. Biol. 78, 1-6. http://dx.doi.org/10.1007/BF00392964.

Duprat, L.P.A.M., Bigg, G.R., Wilton, D.J., 2016. Enhanced Southern Ocean marine productivity due to fertilization by giant icebergs. Nat. Geosci. 9, 219-221. http: //dx.doi.org/10.1038/ngeo2633.

Fischer, G., Gersonde, R., Wefer, G., 2002. Organic carbon, biogenic silica and diatom fluxes in the marginal winter sea-ice zone and in the Polar Front Region: interannual variations and differences in composition. Deep Sea Res. Part II: Top. Stud. Oceanogr. 49, 1721-1745. http://dx.doi.org/10.1016/S0967-0645(02)00009-7.
Funkhouser, J.W., Evitt, W.R., 1959. Preparation techniques for acid-insoluble microfossils. Micropaleontology 5, 369-375. http://dx.doi.org/10.2307/1484431.

Garrison, D.L., 1981. Monterey bay phytoplankton. II. Resting spore cycles in coastal diatom populations. J. Plankton Res. 3, 137-156. http://dx.doi.org/10.1093/ plankt/3.1.137.

Graníi, E., Granéli, W., Rabbani, M.M., Daugbjerg, N., Fransz, G., Roudy, J.C., Alder, V. A., 1993. The influence of copepod and krill grazing on the species composition of phytoplankton communities from the Scotia Weddell sea. Polar Biol. 13, 201-213. http://dx.doi.org/10.1007/BF00238930.

Grigorov, I., Rigual-Hernandez, A.S., Honjo, S., Kemp, A.E.S., Armand, L.K., 2014 Settling fluxes of diatoms to the interior of the Antarctic circumpolar current along 170W. Deep Sea Res. Part I: Oceanogr. Res. Pap. 93, 1-13. http://dx.doi. org/10.1016/j.dsr.2014.07.008.

Grossart, H.-P., Ploug, H., 2001. Microbial degradation of organic carbon and nitrogen on diatom aggregates. Limnol. Oceanogr. 46, 267-277. http://dx.doi.org/ 10.4319/10.2001.46.2.0267.

Hasle, G.R., Syvertsen, E.E., 1997. Chapter 2 - marine diatoms. In: Tomas, C.R. (Ed.), Identifying Marine Phytoplankton. Academic Press, San Diego, pp. 5-385.

Hawkings, J.R., Wadham, J.L., Tranter, M., Raiswell, R., Benning, L.G., Statham, P.J., Tedstone, A., Nienow, P., Lee, K., Telling, J., 2014. Ice sheets as a significant source of highly reactive nanoparticulate iron to the oceans. Nat. Commun. 5, 3929. http://dx.doi.org/10.1038/ncomms4929.

Hillebrand, H., Dürselen, C.-D., Kirschtel, D., Pollingher, U., Zohary, T., 1999. Biovolume calculation for pelagic and benthic microalgae. J. Phycol. 35, 403-424. http://dx.doi.org/10.1046/j.1529-8817.1999.3520403.x.

Honjo, S., Francois, R., Manganini, S., Dymond, J., Collier, R., 2000. Particle fluxes to the interior of the Southern Ocean in the Western Pacific sector along $170^{\circ} \mathrm{W}$. Deep Sea Res. Part II: Top. Stud. Oceanogr. 47, 3521-3548. http://dx.doi.org/ 10.1016/S0967-0645(00)00077-1.

Huntley, M.E., Lopez, M.D., Karl, D.M., 1991. Top predators in the Southern ocean: a major leak in the biological carbon pump. Science 253, 64-66. http://dx.doi.org/ 10.1126/science.1905841.

Jouandet, M.P., Blain, S., Metzl, N., Brunet, C., Trull, T.W., Obernosterer, I., 2008. A seasonal carbon budget for a naturally iron-fertilized bloom over the Kerguelen Plateau in the Southern Ocean. Deep Sea Res. Part II: Top. Stud. Oceanogr. 55, 856-867. http://dx.doi.org/10.1016/j.dsr2.2007.12.037.

Jungandreas, A., Wagner, H., Wilhelm, C., 2012. Simultaneous measurement of the silicon content and physiological parameters by FTIR spectroscopy in diatoms with siliceous cell walls. Plant Cell Physiol. 53, 2153-2162. http://dx.doi.org/ $10.1093 / \mathrm{pcp} / \mathrm{pcs} 144$

Korb, R.E., Whitehouse, M., 2004. Contrasting primary production regimes around South Georgia, Southern Ocean: large blooms versus high nutrient, low chlorophyll waters. Deep Sea Res. Part I: Oceanogr. Res. Pap. 51, 721-738. http://dx. doi.org/10.1016/j.dsr.2004.02.006.

Korb, R.E., Whitehouse, M.J., Atkinson, A., Thorpe, S.E., 2008. Magnitude and maintenance of the phytoplankton bloom at South Georgia: a naturally ironreplete environment. Mar. Ecol. Prog. Ser. 368, 75-91. http://dx.doi.org/ 10.3354/meps07525.

Korb, R.E., Whitehouse, M.J., Gordon, M., Ward, P., Poulton, A.J., 2010. Summer microplankton community structure across the Scotia Sea: implications for biological carbon export. Biogeosciences 7, 343-356. http://dx.doi.org/10.5194/ bg-7-343-2010.

Korb, R.E., Whitehouse, M.J., Ward, P., Gordon, M., Venables, H.J., Poulton, A.J., 2012. Regional and seasonal differences in microplankton biomass, productivity, and structure across the Scotia Sea: implications for the export of biogenic carbon. Deep Sea Res. Part II: Top. Stud. Oceanogr. 59-60, 67-77. http://dx.doi.org/ 10.1016/j.dsr2.2011.06.006.

Kuwata, A., Hama, T., Takahashi, M., 1993. Ecophysiological characterization of two life forms, resting spores and resting cells, of a marine planktonic diatom. Mar. Ecol. Prog. Ser. 102, 245-255.

Kuwata, A., Tsuda, A., 2005. Selection and viability after ingestion of vegetative cells, resting spores and resting cells of the marine diatom, Chaetoceros pseudocurvisetus, by two copepods. J. Exp. Mar. Biol. Ecol. 322, 143-151. http: //dx.doi.org/10.1016/j.jembe.2005.02.013.

Lampitt, R.S., Salter, I., Johns, D., 2009. Radiolaria: major exporters of organic carbon to the deep ocean. Glob. Biogeochem. Cycles 23, GB1010. http://dx.doi.org/ 10.1029/2008GB003221.

Lam, P.J., Bishop, J.K.B., 2007. High biomass, low export regimes in the Southern Ocean. Deep Sea Res. Part II: Top. Stud. Oceanogr. 54, 601-638. http://dx.doi. org/10.1016/j.dsr2.2007.01.013.

Lam, P.J., Doney, S.C., Bishop, J.K.B., 2011. The dynamic ocean biological pump: Insights from a global compilation of particulate organic carbon, $\mathrm{CaCO}_{3}$, and opal concentration profiles from the mesopelagic. Glob. Biogeochem. Cycles 25, GB3009. http://dx.doi.org/10.1029/2010GB003868.

Laws, E.A., D'Sa, E., Naik, P., 2011. Simple equations to estimate ratios of new or export production to total production from satellite-derived estimates of sea surface temperature and primary production. Limnol. Oceanogr. Methods 9, 593-601. http://dx.doi.org/10.4319/lom.2011.9.593.

Le Moigne, F.A.C., Henson, S.A., Cavan, E., Georges, C., Pabortsava, K., Achterberg, E. P., Ceballos-Romero, E., Zubkov, M., Sanders, R.J., 2016. What causes the inverse relationship between primary production and export efficiency in the Southern Ocean? Geophys. Res. Lett. . http://dx.doi.org/10.1002/2016GL068480

Loscher, B.M., De Baar, H.J.W., De Jong, J.T.M., Veth, C., Dehairs, F., 1997. The distribution of Fe in the antarctic circumpolar current. Deep Sea Res. Part II: Top. Stud. Oceanogr. 44, 143-187. http://dx.doi.org/10.1016/S0967-0645(96) 00101-4. 
Maiti, K., Charette, M.A., Buesseler, K.O., Kahru, M., 2013. An inverse relationship between production and export efficiency in the Southern Ocean. Geophys. Res. Lett. 40, 1557-1561. http://dx.doi.org/10.1002/grl.50219.

Manno, C., Stowasser, G., Enderlein, P., Fielding, S., Tarling, G.A., 2015. The contribution of zooplankton faecal pellets to deep-carbon transport in the Scotia Sea (Southern Ocean). Biogeosciences 12, 1955-1965. http://dx.doi.org/10.5194/ bg-12-1955-2015.

Manno, C., Stowasser, G., Enderlein, P., Fielding, S., Tarling, G.A., 2014. The contribution of zooplankton faecal pellets to deep carbon transport in the Scotia Sea (Southern Ocean). Biogeosci. Discuss 11, 16105-16134. http://dx.doi.org/ 10.5194/bgd-11-16105-2014.

Martin, J.H., 1990. Glacial-interglacial $\mathrm{CO}_{2}$ change: the iron hypothesis. Paleoceanography 5, 1-13. http://dx.doi.org/10.1029/PA005i001p00001.

McQuoid, M.R., Hobson, L.A., 1996. Diatom Resting Stages. J. Phycol. 32, 889-902. http://dx.doi.org/10.1111/j.0022-3646.1996.00889.x.

Menden-Deuer, S., Lessard, E.J., 2000. Carbon to volume relationships for dinoflagellates, diatoms, and other protist plankton. Limnol. Oceanogr. 45, 569-579. http://dx.doi.org/10.4319/1o.2000.45.3.0569.

Mengelt, C., Abbott, M.R., Barth, J.A., Letelier, R.M., Measures, C.I., Vink, S., 2001. Phytoplankton pigment distribution in relation to silicic acid, iron and the physical structure across the Antarctic Polar Front, $170^{\circ} \mathrm{W}$, during austral summer. Deep Sea Res. Part II: Top. Stud. Oceanogr. 48, 4081-4100. http://dx. doi.org/10.1016/S0967-0645(01)00081-9.

Meredith, M.P., Watkins, J.L., Murphy, E.J., Cunningham, N.J., Wood, A.G., Korb, R., Whitehouse, M.J., Thorpe, S.E., Vivier, F., 2003. An anticyclonic circulation above the Northwest Georgia Rise, Southern Ocean. Geophys. Res. Lett. 30, 2061. http: //dx.doi.org/10.1029/2003GL018039.

Meskhidze, N., Nenes, A., Chameides, W.L., Luo, C., Mahowald, N., 2007. Atlantic Southern Ocean productivity: Fertilization from above or below? Glob. Biogeochem. Cycles 21, GB2006. http://dx.doi.org/10.1029/2006GB002711.

Moore, J.K., Abbott, M.R., 2000. Phytoplankton chlorophyll distributions and primary production in the Southern Ocean. J. Geophys. Res. Oceans 105, 28709-28722. http://dx.doi.org/10.1029/1999JC000043.

Moore, J.K., Abbott, M.R., Richman, J.G., 1999. Location and dynamics of the Antarctic Polar Front from satellite sea surface temperature data. J. Geophys. Res. Oceans 104, 3059-3073. http://dx.doi.org/10.1029/1998JC900032.

Mortlock, R.A., Froelich, P.N., 1989. A simple method for the rapid determination of biogenic opal in pelagic marine sediments. Deep Sea Res. Part I: Oceanogr. Res. Pap. 36, 1415-1426. http://dx.doi.org/10.1016/0198-0149(89)90092-7.

Nelson, D.M., Tréguer, P., Brzezinski, M.A., Leynaert, A., Quéguiner, B., 1995. Production and dissolution of biogenic silica in the ocean: revised global estimates, comparison with regional data and relationship to biogenic sedimentation. Glob. Biogeochem. Cycles 9, 359-372. http://dx.doi.org/10.1029/95GB01070.

Nielsdóttir, M.C., Bibby, T.S., Moore, C.M., Hinz, D.J., Sanders, R., Whitehouse, M. Korb, R., Achterberg, E.P., 2012. Seasonal and spatial dynamics of iron availability in the Scotia Sea. Mar. Chem. 130-131, 62-72. http://dx.doi.org/10.1016/j. marchem.2011.12.004.

Nodder, S.D., Chiswell, S.M., Northcote, L.C., 2016. Annual cycles of deep-ocean biogeochemical export fluxes in subtropical and subantarctic waters, southwest Pacific Ocean. J. Geophys. Res. Oceans . http://dx.doi.org/10.1002/2015JC011243.

Obernosterer, I., Christaki, U., Lefèvre, D., Catala, P., Van Wambeke, F., Lebaron, P., 2008. Rapid bacterial mineralization of organic carbon produced during a phytoplankton bloom induced by natural iron fertilization in the Southern Ocean. Deep Sea Res. Part II: Top. Stud. Oceanogr. 55, 777-789. http://dx.doi. org/10.1016/j.dsr2.2007.12.005.

Oku, O., Kamatani, A., 1997. Resting spore formation of the marine planktonic diatom Chaetoceros anastomosans induced by high salinity and nitrogen depletion. Mar. Biol. 127, 515-520. http://dx.doi.org/10.1007/s002270050040.

Park, J., Oh, I.-S., Kim, H.-C., Yoo, S., 2010. Variability of SeaWiFs chlorophyll-a in the southwest Atlantic sector of the Southern Ocean: strong topographic effects and weak seasonality. Deep Sea Res. Part I: Oceanogr. Res. Pap. 57, 604-620. http://dx.doi.org/10.1016/j.dsr.2010.01.004.

Pilskaln, C.H., Manganini, S.J., Trull, T.W., Armand, L., Howard, W., Asper, V.L., Massom, R., 2004. Geochemical particle fluxes in the Southern Indian Ocean seasonal ice zone: Prydz Bay region East Antarctica. Deep Sea Res. Part I: Oceanogr. Res. Pap. 51, 307-332. http://dx.doi.org/10.1016/j.dsr.2003.10.010.

Pollard, R.T., Salter, I., Sanders, R.J., Lucas, M.I., Moore, C.M., Mills, R.A., Statham, P.J., Allen, J.T., Baker, A.R., Bakker, D.C.E., Charette, M.A., Fielding, S., Fones, G.R., French, M., Hickman, A.E., Holland, R.J., Hughes, J.A., Jickells, T.D., Lampitt, R.S., Morris, P.J., Nédélec, F.H., Nielsdóttir, M., Planquette, H., Popova, E.E., Poulton, A. J., Read, J.F., Seeyave, S., Smith, T., Stinchcombe, M., Taylor, S., Thomalla, S., Venables, H.J., Williamson, R., Zubkov, M.V., 2009. Southern Ocean deep-water carbon export enhanced by natural iron fertilization. Nature 457, 577-580. http://dx.doi.org/10.1038/nature07716.

Pondaven, P., Ragueneau, O., Tréguer, P., Hauvespre, A., Dezileau, L., Reyss, J.L., 2000. Resolving the "opal paradox" in the Southern Ocean. Nature 405, 168-172. http: //dx.doi.org/10.1038/35012046.

Poulton, A.J., Mark Moore, C., Seeyave, S., Lucas, M.I., Fielding, S., Ward, P., 2007. Phytoplankton community composition around the Crozet Plateau, with emphasis on diatoms and Phaeocystis. Deep Sea Res. Part II: Top. Stud. Oceanogr. 54, 2085-2105. http://dx.doi.org/10.1016/j.dsr2.2007.06.005.

Quéguiner, B., 2013. Iron fertilization and the structure of planktonic communities in high nutrient regions of the Southern Ocean. Deep Sea Res. Part II: Top. Stud. Oceanogr. 90, 43-54. http://dx.doi.org/10.1016/j.dsr2.2012.07.024.

Ragueneau, O., Schultes, S., Bidle, K., Claquin, P., Moriceau, B., 2006. Si and C interactions in the world ocean: importance of ecological processes and implications for the role of diatoms in the biological pump. Glob. Biogeochem. Cycles 20, GB4S02. http://dx.doi.org/10.1029/2006GB002688.

Ragueneau, O., Tréguer, P., Leynaert, A., Anderson, R.F., Brzezinski, M.A., DeMaster, D.J., Dugdale, R.C., Dymond, J., Fischer, G., François, R., Heinze, C., Maier-Reimer E., Martin-Jézéquel, V., Nelson, D.M., Quéguiner, B., 2000. A review of the Si cycle in the modern ocean: recent progress and missing gaps in the application of biogenic opal as a paleoproductivity proxy. Glob. Planet Change 26, 317-365. http://dx.doi.org/10.1016/S0921-8181(00)00052-7.

Rembauville, M., Blain, S., Armand, L., Quéguiner, B., Salter, I., 2015a. Export fluxes in a naturally iron-fertilized area of the Southern Ocean - Part 2: importance of diatom resting spores and faecal pellets for export. Biogeosciences 12 , 3171-3195. http://dx.doi.org/10.5194/bg-12-3171-2015.

Rembauville, M., Meilland, J., Ziveri, P., Schiebel, R., Blain, S., Salter, I., 2016. Planktic foraminifer and coccolith contribution to carbonate export fluxes over the central Kerguelen Plateau. Deep Sea Res. Part I: Oceanogr. Res. Pap. 111, 91-101. http://dx.doi.org/10.1016/j.dsr.2016.02.017.

Rembauville, M., Salter, I., Leblond, N., Gueneugues, A., Blain, S., 2015b. Export fluxes in a naturally iron-fertilized area of the Southern Ocean - Part 1: seasonal dynamics of particulate organic carbon export from a moored sediment trap. Biogeosciences 12, 3153-3170. http://dx.doi.org/10.5194/bg-12-3153-2015.

Reynolds, R.W., Rayner, N.A., Smith, T.M., Stokes, D.C., Wang, W., 2002. An improved in situ and satellite SST analysis for climate. J. Clim. 15, 1609-1625. http://dx. doi.org/10.1175/1520-0442(2002)015 < 1609:AIISAS > 2.0.CO;2.

Rigual-Hernández, A.S., Trull, T.W., Bray, S.G., Closset, I., Armand, L.K., 2015a. Seasonal dynamics in diatom and particulate export fluxes to the deep sea in the Australian sector of the southern Antarctic Zone. J. Mar. Syst. 142, 62-74. http: //dx.doi.org/10.1016/j.jmarsys.2014.10.002.

Rigual-Hernández, A.S., Trull, T.W., Bray, S.G., Cortina, A., Armand, L.K., 2015b. Latitudinal and temporal distributions of diatom populations in the pelagic waters of the Subantarctic and Polar Frontal zones of the Southern Ocean and their role in the biological pump. Biogeosciences 12, 5309-5337. http://dx.doi.org/ 10.5194/bg-12-5309-2015.

Romero, O.E., Armand, L., 2010. Marine diatoms as indicators of modern changes in oceanographic conditions, The Diatoms: Applications for the Environmental and Earth Sciences, 2nd Ed. Camb. Univ. Press, pp. 373-400.

Rynearson, T.A., Richardson, K., Lampitt, R.S., Sieracki, M.E., Poulton, A.J., Lyngsgaard, M.M., Perry, M.J., 2013. Major contribution of diatom resting spores to vertical flux in the sub-polar North Atlantic. Deep Sea Res. Part I: Oceanogr. Res. Pap. 82, 60-71. http://dx.doi.org/10.1016/j.dsr.2013.07.013.

Salter, I., Kemp, A.E.S., Lampitt, R.S., Gledhill, M., 2010. The association between biogenic and inorganic minerals and the amino acid composition of settling particles. Limnol. Oceanogr. 55, 2207-2218. http://dx.doi.org/10.4319/ o.2010.55.5.2207

Salter, I., Kemp, A.E.S., Moore, C.M., Lampitt, R.S., Wolff, G.A., Holtvoeth, J., 2012 Diatom resting spore ecology drives enhanced carbon export from a naturally iron-fertilized bloom in the Southern Ocean. Glob. Biogeochem. Cycles 26 GB1014. http://dx.doi.org/10.1029/2010GB003977.

Salter, I., Schiebel, R., Ziveri, P., Movellan, A., Lampitt, R., Wolff, G.A., 2014. Carbonate counter pump stimulated by natural iron fertilization in the Polar Frontal Zone. Nat. Geosci. 7, 885-889. http://dx.doi.org/10.1038/ngeo2285.

Sanders, J.G., Cibik, S.J., 1985. Reduction of growth rate and resting spore formation in a marine diatom exposed to low levels of cadmium. Mar. Environ. Res. 16, 165-180. http://dx.doi.org/10.1016/0141-1136(85)90136-9.

Schrader, H.J., Gersonde, R., 1978. Diatoms and silicofagellates. Micropaleontological counting methods and techniques: an exercise on an eight metres section of the Lower Pliocene of Capo Rosello, Sicily. Utrecht Micropaleontol. Bull., 129-176.

Siegel, D.A., Deuser, W.G., 1997. Trajectories of sinking particles in the Sargasso Sea: modeling of statistical funnels above deep-ocean sediment traps. Deep Sea Res. Part I: Oceanogr. Res. Pap. 44, 1519-1541. http://dx.doi.org/10.1016/S0967-0637 (97)00028-9.

Smetacek, V., Assmy, P., Henjes, J., 2004. The role of grazing in structuring Southern Ocean pelagic ecosystems and biogeochemical cycles. Antarct. Sci. 16, 541-558. http://dx.doi.org/10.1017/S0954102004002317.

Smetacek, V.S., 1985. Role of sinking in diatom life-history cycles: ecological, evolutionary and geological significance. Mar. Biol. 84, 239-251. http://dx.doi.org/ 10.1007/BF00392493.

Smith Jr., W.O., Nelson, D.M., 1986. Importance of ice edge phytoplankton production in the Southern Ocean. BioScience 36, 251-257. http://dx.doi.org/ $10.2307 / 1310215$.

Sugie, K., Kuma, K., 2008. Resting spore formation in the marine diatom Thalassiosira nordenskioeldii under iron- and nitrogen-limited conditions. J. Plankton Res. 30, 1245-1255. http://dx.doi.org/10.1093/plankt/ fbn080.

Sugie, K., Kuma, K., Fujita, S., Ikeda, T., 2010. Increase in Si:N drawdown ratio due to resting spore formation by spring bloom-forming diatoms under Fe- and $\mathrm{N}$-limited conditions in the Oyashio region. J. Exp. Mar. Biol. Ecol. 382, 108-116. http://dx.doi.org/10.1016/j.jembe.2009.11.001.

Suzuki, H., Sasaki, H., Fukuchi, M., 2001. Short-term variability in the flux of rapidly sinking particles in the Antarctic marginal ice zone. Polar Biol. 24, 697-705. http://dx.doi.org/10.1007/s003000100271.

Tesi, T., Langone, L., Ravaioli, M., Giglio, F., Capotondi, L., 2012. Particulate export and lateral advection in the Antarctic Polar Front (Southern Pacific Ocean): oneyear mooring deployment. J. Mar. Syst. 105-108, 70-81. http://dx.doi.org/ 10.1016/j.jmarsys.2012.06.002.

Thorpe, S.E., Heywood, K.J., Brandon, M.A., Stevens, D.P., 2002. Variability of the 
southern Antarctic Circumpolar Current front north of South Georgia. J. Mar. Syst. Phys. Biol. Ocean Fronts 37, 87-105. http://dx.doi.org/10.1016/S0924-7963 (02)00197-5.

Twining, B.S., Nodder, S.D., King, A.L., Hutchins, D.A., LeCleir, G.R., DeBruyn, J.M., Maas, E.W., Vogt, S., Wilhelm, S.W., Boyd, P.W., 2014. Differential remineralization of major and trace elements in sinking diatoms. Limnol. Oceanogr. 59, 689-704. http://dx.doi.org/10.4319/lo.2014.59.3.0689.

van der Merwe, P., Bowie, A.R., Quéroué, F., Armand, L., Blain, S., Chever, F., Davies, D., Dehairs, F., Planchon, F., Sarthou, G., Townsend, A.T., Trull, T.W., 2015. Sourcing the iron in the naturally fertilised bloom around the Kerguelen Plateau: particulate trace metal dynamics. Biogeosciences 12, 739-755. http://dx doi.org/10.5194/bg-12-739-2015.

van der Merwe, P., Lannuzel, D., Bowie, A.R., Meiners, K.M., 2011. High temporal resolution observations of spring fast ice melt and seawater iron enrichment in East Antarctica. J. Geophys. Res. Biogeosci. 116, G03017. http://dx.doi.org/ 10.1029/2010JG001628.

van Sebille, E., Scussolini, P., Durgadoo, J.V., Peeters, F.J.C., Biastoch, A., Weijer, W., Turney, C., Paris, C.B., Zahn, R., 2015. Ocean currents generate large footprints in marine palaeoclimate proxies. Nat. Commun. 6, 6521. http://dx.doi.org/10.1038/ ncomms7521.

Ward, P., Atkinson, A., Venables, H.J., Tarling, G.A., Whitehouse, M.J., Fielding, S., Collins, M.A., Korb, R., Black, A., Stowasser, G., Schmidt, K., Thorpe, S.E., Enderlein, P., 2012. Food web structure and bioregions in the Scotia Sea: a seasonal synthesis. Deep Sea Res. Part II: Top. Stud. Oceanogr. 59-60, 253-266. http://dx.doi.org/10.1016/j.dsr2.2011.08.005.

Ward, P., Whitehouse, M., Meredith, M., Murphy, E., Shreeve, R., Korb, R., Watkins, J., Thorpe, S., Woodd-Walker, R., Brierley, A., Cunningham, N., Grant, S., Bone, D., 2002. The Southern Antarctic circumpolar current front: physical and biological coupling at South Georgia. Deep Sea Res. Part I: Oceanogr. Res. Pap. 49, 2183-2202. http://dx.doi.org/10.1016/S0967-0637(02)00119-X.

Westberry, T.K., Behrenfeld, M.J., Milligan, A.J., Doney, S.C., 2013. Retrospective satellite ocean color analysis of purposeful and natural ocean iron fertilization. Deep Sea Res. Part I: Oceanogr. Res. Pap. 73, 1-16. http://dx.doi.org/10.1016/j. dsr.2012.11.010.

Whitehouse, M.J., Atkinson, A., Korb, R.E., Venables, H.J., Pond, D.W., Gordon, M., 2012. Substantial primary production in the land-remote region of the central and northern Scotia Sea. Deep Sea Res. Part II: Top. Stud. Oceanogr. 59-60, 47-56. http://dx.doi.org/10.1016/j.dsr2.2011.05.010 (DISCOVERY 2010: Spatial and Temporal Variability in a Dynamic Polar Ecosystem).

Whitehouse, M.J., Priddle, J., Brandon, M.A., 2000. Chlorophyll/nutrient characteristics in the water masses to the north of South Georgia, Southern Ocean. Polar Biol. 23, 373-382. http://dx.doi.org/10.1007/s003000050458.

Whitehouse, M.J., Priddle, J., Symon, C., 1996. Seasonal and annual change in seawater temperature, salinity, nutrient and chlorophyll a distributions around South Georgia, South Atlantic. Deep Sea Res. Part I: Oceanogr. Res. Pap. 43, 425-443. http://dx.doi.org/10.1016/0967-0637(96)00020-9. 